\title{
Evaluation of Reinforcing Steel of Chloride Induced Corrosion using Half-Cell Potential and Concrete Resistivity Measurements
}

\author{
Gwarah Ledum S. ${ }^{1}$, Macmammah Michael ${ }^{2}$, Charles Kennedy ${ }^{3}$ \\ ${ }^{1,3}$ School of Engineering, Department of Civil Engineering, Kenule Beeson Saro-Wiwa \\ Polytechnic, Bori, Rivers State, Nigeria \\ ${ }^{2}$ School of Engineering, Department of Electrical / Electronics Engineering, Kenule Beeson \\ Saro-Wiwa Polytechnic, Bori, Rivers State, Nigeria \\ Authors E-mail: ${ }^{1}$ gledsnig@yahoo.com, ${ }^{2}$ mie4tammy@gmail.com, ${ }^{3}$ ken_charl@yahoo.co.uk,
}

\section{ABSTRACT \\ The investigative studies assessed the controlled of corrosion potential probability resulting} from harsh and severe environment with the application of Daniellia oliveri exudates/resin as an inhibitive materials against corrosion. The exudates/resin is coated directly to reinforcing steel of different thicknesses, embedded in concrete slabs, and exposed to an induced accelerated corrosion media of high salt content. The hardened concrete slabs are completely immersed in 5\% sodium chloride $(\mathrm{NaCl})$ solution in water and accelerated for a rapid corrosion process for 360 days with interval checks and routine tests of 90 days, 180 days, 270 days, and 360 days for calculations, and record documentation for comparison. The corrosion potential $\mathrm{E}_{\text {corr }}, \mathrm{mV}$ maximum computed values of the controlled and coated samples were $-104.43 \mathrm{mV}$ and $-118.79 \mathrm{mV}$, which showed the relationship between corrosion potential and indication in the reference range $E_{\text {corr }}>-200 \mathrm{mV}$. The results from this potential $\mathrm{E}_{\text {corr }}$ result show that the values of controlled samples and exudates/resin coated samples are low, with a $90 \%$ probability that the reinforcement in this area will not corrode during measurement (10\% risk of corrosion). The maximum calculated value of corroded is $275.86 \mathrm{mV}$, the result is of the reference value of the relationship between corrosion potential and probability of $-350 \mathrm{mV} \leq E_{\text {corr }} \leq-200 \mathrm{mV}$ indicates a high-value range of $10 \%$ or an uncertain corrosion probability. The results of the controlled and coated concrete resistivity samples obtained a maximum average value of $14.37 \mathrm{k} \Omega \mathrm{cm}$ and $12.24 \mathrm{k} \Omega \mathrm{cm}$ with a description of the value $10<\rho<20$ (low) compared to the corrosion value of $8.89 \mathrm{k} \Omega \mathrm{cm}$ with specifications $5<\rho<10$ (high). The calculated maximum percentile value of the controlled yield strength was $7.44 \%$ compared to the corroded and coated values $-5.82 \%$ and $6.62 \%$ and the possible differential values were $1.38 \%$ controlled, $0.39 \%$ corroded and $0.44 \%$ coated. The ultimate tensile strength maximum calculated percentile of the controlled tensile strength is $0.99 \%$ relative to corroded and the coated value is $-1.02 \%$ and $1.95 \%$ respectively and the potential differential value $0.69 \%$ controlled, $0.89 \%$ corroded and $0.92 \%$ coated. The strain ratio maximum percentile value calculated for comparison was checked $-5.17 \%$ versus corroded $-5.09 \%$ and coated $-4.33 \%$, and different peak values checked is $1.39 \%$, corroded $0.57 \%$ and covered $0.52 \%$. The comparison results show that the low load carrying capacity is caused by the effect of corrosion attack on the uncoated (corroded) elements, which interfere with reinforcing steel fibers, ribs and passive formation and surface modification. The observed average values for the coated samples were traced back to the potential for corrosion resistivity to penetrate the reinforcing steel with the formation of a protective membrane. The cross-sectional area relative average and differential in percentile values between coated and corroded samples ranged from $26.61 \%$ to $-20.77 \%$. 
The decrease in average and percentile values indicated that the corrosion effect led to a reduction in diameter and cross-sectional area, fiber degradation, rib reduction, and surface modification, whereas elements coated with exudate/resin. For comparison, the results obtained show a reduction of rebar unit weight after corrosion in the average and percentile values for coated from $0.965 \mathrm{~kg}$ to $0.877 \mathrm{~kg}$ and corrosion $14.65 \%$ to $-12.66 \%$. The combined results show that the corrosion effect on the corroded samples causes a decrease/decrease in weight compared to coatings with percentile loading and an increase in average values, which causes a slight increase in volume with coating thickness.

Key Words: Corrosion, Corrosion inhibitors, corrosion potential, concrete resistivity and Steel Reinforcement

\section{INTRODUCTION}

It is well known that chloride-induced corrosion is a major cause of wear in reinforced concrete structures. Chloride can come from several sources. It can be dispersed in concrete when the structure is exposed to seawater, saline groundwater, spray or de-icing salts. It can also be cast into concrete if chloride-contaminated feedstock is used for the concrete or through additives such as calcium chloride, which was used as a cement hydration accelerator in Europe until the mid-1970s ([1]; [2]; [3]; [4]). Although chloride ions have only a small effect on the $\mathrm{pH}$ value of the pore solution of concrete, they have the ability to de-pass steel in concrete even under strongly alkaline conditions ([5]). Once present in the concrete, some chloride ions remain free in the pore solution, while others bind chemically to the hydration products of the cement.

Inhibitors and Greener pathway inhibitors are highly effective and natural, free of toxicity, usually, cheap and cheap for future use, depending on these properties, there is a great need for green inhibitors for biomaterials because of their innate properties ([6]). In the last two decades, research in the field of " green "corrosion inhibitors has focused on the purpose of using cheap, effective low-cost molecules or the environmental impact of " zero " ([7]). Plant extracts are considered to be an incredibly rich source of synthetic organic compounds that can be produced in simple processes at low cost and are environmentally friendly. The use of these natural products such as compounds extracted from leaves or seeds as corrosion inhibitors has been widely reported by several authors ([8], [9], [10] [11], [6], [12],[13],[15], [16], [17], [18],[19])

[20] assessed the utilization of naturally inorganic exudates/gums extracted from trees bark of invingia gabonensis, coated to steel reinforcement with changing thicknesses, immersed in sodium chloride for corrosion assessments in examination with non-ccoated and control tests for 150 days quickened process with applied current of $-200 \mathrm{mV}$ through $1200 \mathrm{mV}$, with an output pace of $1 \mathrm{mV} / \mathrm{s}$. Summary results of the exudates / resin coated specimens indicated the absence of corrosion, the results have been confirmed in invingia gabonensis exudates / resins as a good corrosion inhibitor. The results of cross-sectional reduction showed higher percentile reduction rates due to the disappearance of fiber loss in reinforcing steel resulting from the occurrence of corrosion. The weight loss results of the reinforcing steel showed higher percentile values against the control and the coated due to the corrosion effect of the reinforcing steel. The results showed small loads in the highest delivery of the control mold types and composite types resulting from the reduction of mechanical properties of the steel reinforcement. 
[21] Evaluated the effect of uncoated and exudates / resin coated reinforcements with Celtis Zenkeri of $150 \mu \mathrm{m}, 300 \mu \mathrm{m}$ and $450 \mu \mathrm{m}$ different thicknesses, inserted into the concrete slab, and accelerated corrosion potential rates and mechanical properties for 150 days. Strength of steel using half-cell potential, concrete resistivity measurement, tensile strength tests were evaluated. The results of the weight loss of steel showed a high percentile of values against the control and coated models due to the effect of corrosion on the mechanical properties of the steel. Cross-sectional area reduction results showed higher percentile reduction values due to the effect of corrosion on the mechanical properties of steel.

[22] suggested that in the active state the B-value in the Stern-Geary equation is $26 \mathrm{mV}$, and in the sensitive state $52 \mathrm{mV}$. Using equation (2.21), a value $\mathrm{B}=26 \mathrm{mV}$ can be obtained if both Tafel mounts are equal to $120 \mathrm{mV} /$ tenth; and for $\mathrm{B}=52 \mathrm{mV}$ one of the Tafel Mountains can be infinity and the other $120 \mathrm{mV} /$ tenth.

[21] Song, (2000) He suggested that the amount of B iron in the concrete may vary from $8 \mathrm{mV}$ to near infiltration under different conditions.

[22] Carried out tensile tests of corrosion potential, concrete resistivity, and control were investigated by the corroded and coated reinforcing steel of the concrete slab members. Compared to coated specimens, corroded has an increased corrosion potential of $70.1 \%$ and concrete resistivity values decreased by $38.8 \%$, yield stress against corroded decreased by $100 \%$ nominal yield stress against $100.95 \%$ to $96.12 \%$ respectively, weight loss cross sectional diameter from $48.5 \%$ to $67.5 \%$. Overall results showed that dacryoides edulis acted as an inhibitor, which sustained and protected against reinforcing steel the harsh environment. [23] assessed the use of inorganic eco-friendly exudates / resin extract from cola acuminate as a preventive measure of salt water attack on embedded reinforcing steel in concrete structures in marine areas using an experimental application of half-area probability. The results showed a high ultimate yield of the corruoded specimens to control and coating specimens due to the effect of corrosion on the mechanical properties of steel reinforcement. The results of the weight loss of steel showed a high percentile of values against the control and coated models due to the effect of corrosion on the mechanical properties of the steel.

[24] Investigated the strength of corrosion, concrete formulation and critical examination of non-corrosive, corrosive, and coated members. Direct application of the corrosion inhibitor of dacryode edulis resins in size $150 \mu \mathrm{m}, 250 \mu \mathrm{m}, 350 \mu \mathrm{m}$ was coatedd into a $12 \mathrm{~mm}$ thickness, placed in a concrete slab and exposed to a corrosive environment of 119 days for rapid corrosion testing, a partial measurement resumption estimates and static tests. Compared with the corroded samples, the corroded has a $70.1 \%$ increased values and a $38.8 \%$ reduction in the concrete resistivity values. Comparatively, controlled and coated exhibited high yield strength low failure load as compared to the corroded. Higher percentile a value of crosssectional area reduction of the diameter was recorded in corroded as compared to the controlled and coated members.

[25] Measured the rapid process with the acceleration process of the corroded and inhibited members with thicknesses of $150 \mu \mathrm{m}$, and $250 \mu \mathrm{m}$ and $350 \mu \mathrm{m}$, and embedded into concrete member (slab) and pond for 119 day in an acqeous solution. Comparatively, corroded has incremental values of Ecorr, $\mathrm{mV}$ and reduction in concrete resistivity, reduction in yield stress as compared to norminal with weight loss and reduction diameter as compared to coated and control members.

[26] Investigated the half cell corrosion measurements, concrete strength tests and tensile strength of corrosion materials, non-coated and coated with Moringa Oleifera lam resin paste. Comparative results showed that the coated samples has reduced values of Ecorr, $\mathrm{mV}$, and increased values of concrete resistivity over corroded of increase in Ecorr, $\mathrm{mV}$ and reduced concrete resistivity. Comparatively, results showed reduction in steel cross sectional diameter, weight loss and reduction in yield stress as to coated members. 
[27] Investigated the use of inorganic inhibitors and Greener method inhibitors to evaluate potential of Mangifera indica resins paste residues coated with of $150 \mu \mathrm{m}, 250 \mu \mathrm{m}$ and $350 \mu \mathrm{m}$. Corrosive samples produced higher values of Ecorr $\mathrm{mV}$ strength and 3decreased of concrete resistivity, decrease in weight and reduction in cross-sectional diameter resulting from sodium chloride attack.

[28] Investigated the eco-friendly inorganic content of Olibanum exudates/resins, coated to steel and of non-coated members, embedded in a concrete slab, and incubated in a corrosive environment for 150 days, potential test rate of $1200 \mathrm{mV}$ to $-200 \mathrm{mV}$. Due to the attack on the mechanical properties of steel reinforcement, high yield results were recorded for non-coated (corroded) specimens against coated specimens. The results of the weight loss of steel indicate a higher percentile of values against the control and coating model, which results in a reduction of the fiber / ribbed properties of the steel and thus the surface strength. The crosssectional expansion of the corrugated specimen results showed high percentile reduction values due to the effect of corrosion on the mechanical properties of the steel.

[29] Investigated the passive loss of reinforcing steel with the use of natural inorganic exudates/resins paste of milicia excelsa with a coating thickness of $150 \mu \mathrm{m}, 300 \mu \mathrm{m}$, and $450 \mu \mathrm{m}$. The coated and uncoated members are embedded in the concrete slab and submerged in a partially fast-flowing media with rapid application currents from $1200 \mathrm{mV}$ to $-200 \mathrm{mV}$, with a scan rate of $1 \mathrm{mV}$ and a scan rate for the non-coated. Due to the effect of fiber / ribbed removal from the surface attack and the effect of corrosion on the mechanical properties of the steel, the non-coated members showed higher percentile values against the control and coating samples. High-end yield and coating patterns of non-coated samples with low load application leading to corrosion on the mechanical properties of steel reinforcement

\section{MATERIALS AND METHODS FOR EXPERINMENT}

\section{Aggregates}

Fine and coarse aggregates are purchased at the sand dumpsite. Both meet the requirements of [3]

\section{Cement}

Cement (lime) 42.5 was used for all concrete mixes. Cement meets the requirements of [31] Water

Water samples were taken from the Civil Engineering Laboratory at Bori, Kenule Beason Polytechnic in River State. Water meets [32]

\section{Structural steel reinforcement}

Reinforcement was purchased directly from the market at Port Harcourt. It conformed to [33] Corrosion Inhibitors (Resins / Exudates) Daniellia Oliveri

The exudates/resins were obtained by tapping from the tree trunk. The trees are abundantly found in southeastern Nigeria. Exudates are gotten from Uli, Ihiala Local Government of Anambra State.

\section{Prepare samples for reinforcement with coated}

The extruding sticky gummy cream was obtained from the tree bark through the tapping process. The resulting exudate/resin is coated directly with reinforcing steel of different thicknesses, embedded in concrete slabs, and exposed to territorial sea areas with high salt content. Of course, the manifestation of corrosion in reinforcement, metals, and related materials is a long-term process that takes many years. However, the artificial introduction of sodium chloride $(\mathrm{NaCl})$ accelerates the rate of corrosion, and its manifestations occur in a short time. The corrosion rate value is calculated by estimating the current density obtained or obtained from the polarization curve and the degree of quantification of the corrosion rate. The concrete mixture was measured with the weight of the material using the manual mixing method using a standard concrete ratio of 1.2.4 and a water-cement ratio of 0.65 . A concrete 
plate measuring $100 \mathrm{~mm} \times 500 \mathrm{~mm} \times 500 \mathrm{~mm}$ (thickness, width, and length) with a concrete cover of $10 \mathrm{~mm}$ is poured into a metal mold, covered with air removed, and reinforced by 10 pieces of reinforcing steel with a diameter of $12 \mathrm{~mm}$, at $100 \mathrm{~mm} \mathrm{c} / \mathrm{c}$ (top and bottom) are placed and molded after 72 hours, compacted for 28 days at standard room temperature to harden. The hardened concrete slabs are completely immersed in 5\% sodium chloride $(\mathrm{NaCl})$ solution in water and accelerated for a rapid corrosion process for 360 days with interval checks and routine tests of 90 days, 180 days, 270 days, and 360 days for calculations and record documentation for comparison.

\section{Accelerated Corrosion Test}

The corrosion process is a natural phenomenon that takes decades to materialize. This is a long-term process, but the fast and accelerated corrosion process using Sodium Chloride $(\mathrm{NaCl})$ plastic allows reinforcement embedded in concrete to undergo corrosion and can simulate the increase in corrosion that will occur over decades in a short time. To test the corrosion resistivity of concrete, experimental processes were developed that accelerated the corrosion process and maximize the corrosion resistivity of concrete. The accelerated corrosion test is an impress current technique, an effective technique for examining the corrosion process of steel in concrete and for assessing damage to the concrete cover protection to the steel bar. The laboratory acceleration process helps distinguish the role of individual factors that can influence chloride-induced corrosion. For the construction of structural elements and corrosion resistivity as well as for the selection of suitable materials and suitable protection systems, an accelerated corrosion test is carried out to obtain quantitative and qualitative information on corrosion.

\section{Corrosion current measurement (Half-Cell Potential Measurement)}

The classification of the severity of reinforcing steel corrosion is shown in Table 2.1. If the potential measurement results indicate a high probability of active corrosion, then the degree of corrosion can be assessed by measuring the resistivity of the concrete. However, care must be taken when using these data as it is assumed that the corrosion rate is constant over time. Measurement of half potential is an indirect method of estimating the probability of corrosion. Recently, there has been much interest in developing tools for carrying out electrochemical measurements of disturbances on the steel itself to obtain a direct estimate of the corrosion rate ([34]). Corrosion rate refers to electrochemical measurements, the first based on data.

Table 2.1: Dependence between potential and corrosion probability [35]

\begin{tabular}{|l|l|}
\hline Potential $E_{\text {corr }}$ & Probability of Corrosion \\
\hline$E$ corr $<-350 \mathrm{mV}$ & $\begin{array}{l}\text { Greater than } 90 \% \text { probability that reinforcing steel corrosion is occurring in } \\
\text { that area at the time of measurement }\end{array}$ \\
\hline$-350 \mathrm{mV} \leq E \mathrm{c}_{\text {orr }} \leq-200 \mathrm{mV}$ & Corrosion activity of the reinforcing steel in that area is uncertain \\
\hline$E_{\text {corr }}>-200 \mathrm{mV}$ & $\begin{array}{l}90 \% \text { probability that no reinforcing steel corrosion is occurring in that area at } \\
\text { the time of measurement (10\% risk of corrosion }\end{array}$ \\
\hline
\end{tabular}

\section{Test for measuring the Resistivity of concrete}

Different measured values are measured at different points on the concrete surface. After the water has been applied to the slab surface, the resistivity of the concrete is measured daily at the reference point to determine its saturation state. The level of slab saturation is monitored by measuring the electrical resistivity of the concrete, which is directly related to the moisture content of the concrete. Before water is applied to the slab, the electrical resistivity of the concrete is measured at certain points in the dry state. The electrical resistivity becomes constant as soon as the concrete reaches saturation. 
Table 2.2: Dependence between concrete resistivity and corrosion probability [36]

Concrete resistivity $\rho, \mathbf{k} \Omega \mathrm{cm}$

$\rho<5$

$5<\rho<10$

$10<\rho<20$

$\rho>20$
Probability of corrosion

Very high

High

Low to moderate

\section{Tensile Strength of Reinforcement}

To determine the yield strength and ultimate tensile strength peak point of the reinforcing steel bar, the concrete slabs are reinforced with 10 numbers of $12 \mathrm{~mm}$ diameter (top and bottom direction) of uncoated and coated reinforcing steel and tested under stress in an Instron Universal testing machine (UTM) to failure. To ensure stability, the remaining cut portions are used for other parameters examinations of rebar diameter before the test, rebar diameter - after corrosion, cross-sectional area reduction/increase, rebar weights- before the test, rebar weights- after corrosion, weight loss /gain of steel.

\section{EXPERIMENTAL RESULTS AND DISCUSSION}

It is used as an indication of the probability of significant corrosion $(\rho<5,5<\rho<10,10<\rho$ $\langle 20, \rho>20)$ for very high, high, low to a moderate and low probability of corrosion. At another measurement point, the potential for correction was high $\left(-350 \mathrm{mV} \leq E_{\text {corr }} \leq-200\right.$ $\mathrm{mV}$ ), indicating a corrosion probability of $10 \%$ or uncertainty. It is proven that if the potential for corrosion is low $(<-350 \mathrm{mV})$ within a certain range, there is a $95 \%$ chance of corrosion. Concrete resistivity is usually measured using the four-electrode method. Resistivity study data show whether certain states are conducive to lower ion movement, leading to greater and more corrosion.

Table 3.1: Potential $E_{\text {corr }}$, after 28 days curing and 360days Accelerated Periods of Control Concrete slab

\begin{tabular}{|c|c|c|c|c|c|c|c|c|c|c|c|c|}
\hline \multicolumn{13}{|c|}{ Specimens } \\
\hline Sample Numbers & DOS & DOS1 & DOS2 & DOS3 & DOS4 & DOS5 & DOS6 & DOS7 & DOS8 & DOS9 & DOS10 & DOS11 \\
\hline & \multicolumn{12}{|c|}{ Time Intervals after 28 days curing } \\
\hline $\begin{array}{l}\text { Sampling and } \\
\text { Durations }\end{array}$ & \multicolumn{3}{|c|}{ Samples 1 ( 28 days) } & \multicolumn{3}{|c|}{ Samples 2 (28 Days) } & \multicolumn{3}{|c|}{ Samples 3 (28 Days) } & \multicolumn{3}{|c|}{ Samples 4 (28 Days) } \\
\hline Potential Ecorr,mV & -111.8 & -109.5 & -105.2 & -103.8 & -106.2 & -103.2 & -111.6 & -107.3 & -102.8 & -105.2 & -109.1 & -110.3 \\
\hline $\begin{array}{l}\text { Concrete Resistivity } \\
\rho, \mathrm{k} \Omega \mathrm{cm}\end{array}$ & 14.24 & 14.24 & 14.23 & 14.23 & 14.22 & 14.38 & 14.38 & 14.37 & 14.37 & 14.36 & 14.30 & 14.22 \\
\hline $\begin{array}{l}\text { Yield } \\
(\mathrm{MPa})\end{array}$ & 452.14 & 449.14 & 452.14 & 452.44 & 451.14 & 450.37 & 453.37 & 453.67 & 452.37 & 453.76 & 450.27 & 454.10 \\
\hline $\begin{array}{l}\text { Ultimate Tensile } \\
\text { Strength, fu }(\mathrm{MPa})\end{array}$ & 613.31 & 611.26 & 612.94 & 608.72 & 612.25 & 612.67 & 612.47 & 613.27 & 611.87 & 613.42 & 612.92 & 612.78 \\
\hline Strain Ratio & 1.36 & 1.36 & 1.36 & 1.35 & 1.36 & 1.36 & 1.35 & 1.35 & 1.35 & 1.35 & 1.36 & 1.35 \\
\hline $\begin{array}{l}\text { Rebar } \quad \text { Diameter } \\
\text { Before Test }(\mathrm{mm})\end{array}$ & 11.98 & 11.96 & 11.97 & 11.99 & 11.96 & 11.98 & 11.98 & 11.96 & 11.97 & 11.97 & 11.96 & 11.97 \\
\hline $\begin{array}{l}\text { Rebar Diamete at } 28 \\
\text { days }(\mathrm{mm})\end{array}$ & 11.98 & 11.96 & 11.97 & 11.99 & 11.96 & 11.98 & 11.98 & 11.96 & 11.97 & 11.97 & 11.96 & 11.97 \\
\hline $\begin{array}{l}\text { Cross- sectional Area } \\
\text { Reduction/Increase } \\
\text { Diameter, } \mathrm{mm})\end{array}$ & 0.00 & 0.00 & 0.00 & 0.00 & 0.00 & 0.00 & 0.00 & 0.00 & 0.00 & 0.00 & 0.00 & 0.00 \\
\hline $\begin{array}{ll}\text { Rebar } & \text { Weights- } \\
\text { Before Test } & \\
\end{array}$ & 0.93 & 0.93 & 0.93 & 0.93 & 0.93 & 0.93 & 0.93 & 0.93 & 0.93 & 0.93 & 0.93 & 0.93 \\
\hline $\begin{array}{l}\text { Rebar Weights- After } \\
\text { at } 28 \text { days }(\mathrm{Kg})\end{array}$ & 0.93 & 0.93 & 0.93 & 0.93 & 0.93 & 0.93 & 0.93 & 0.93 & 0.93 & 0.93 & 0.93 & 0.93 \\
\hline $\begin{array}{l}\text { Weight Loss /Gain of } \\
\text { Steel (Kg) at } 28 \text { days }\end{array}$ & 0.00 & 0.00 & 0.00 & 0.00 & 0.00 & 0.00 & 0.00 & 0.00 & 0.00 & 0.00 & 0.00 & 0.00 \\
\hline
\end{tabular}


DOI : https://dx.doi.org/10.26808/rs.ed.i11v5.04

International Journal of Emerging Trends in Engineering and Development

Issue 11, Vol.5 (Aug-Sep 2021)

Available online on http://www.rspublication.com/ijeted/ijeted_index.htm

ISSN 2249-6149

Table 3.2: Potential Ecorr, after 28 days curing and 360days Accelerated Periods of Corroded Concrete slab Specimens

\begin{tabular}{|c|c|c|c|c|c|c|c|c|c|c|c|c|}
\hline $\begin{array}{ll}\text { Sampling } & \text { and } \\
\text { Durations } & \end{array}$ & \multicolumn{3}{|c|}{ Samples 1 (90 days) } & \multicolumn{3}{|c|}{ Samples 2 (180 Days) } & \multicolumn{3}{|c|}{ Samples 3 (270 Days) } & \multicolumn{3}{|c|}{ Samples 4 (360 Days) } \\
\hline Potential Ecorr,mV & -316.5 & -329.7 & -326.6 & -318.9 & -328.7 & -335.7 & -269.6 & -276.8 & -280.9 & -304.1 & -309.3 & -317.5 \\
\hline $\begin{array}{ll}\text { Concrete } & \text { Resistivity } \\
\rho, \mathrm{k} \Omega \mathrm{cm} & \end{array}$ & 8.52 & 8.66 & 9.49 & 7.20 & 7.18 & 7.13 & 8.95 & 7.30 & 7.34 & 7.94 & 7.31 & 7.13 \\
\hline $\begin{array}{ll}\text { Yield } & \text { Strength, fy } \\
(\mathrm{MPa}) & \end{array}$ & 426.34 & 425.85 & 423.95 & 419.97 & 418.59 & 421.67 & 426.56 & 420.08 & 421.96 & 422.78 & 423.87 & 423.89 \\
\hline $\begin{array}{l}\text { Ultimate } \quad \text { Tensile } \\
\text { Strength, fu }(\mathrm{MPa})\end{array}$ & 606.93 & 612.53 & 607.53 & 609.13 & 611.83 & 605.33 & 608.76 & 610.36 & 613.06 & 606.56 & 609.20 & 605.33 \\
\hline Strain Ratio & 1.42 & 1.44 & 1.43 & 1.45 & 1.46 & 1.44 & 1.43 & 1.45 & 1.45 & 1.43 & 1.44 & 1.43 \\
\hline $\begin{array}{l}\text { Rebar } \quad \text { Diameter } \\
\text { Before Test }(\mathrm{mm})\end{array}$ & 11.99 & 11.97 & 11.98 & 12.00 & 11.97 & 11.99 & 11.99 & 11.97 & 11.97 & 11.97 & 11.97 & 11.98 \\
\hline $\begin{array}{l}\text { Rebar Diameter- After } \\
\text { Corrosion }(\mathrm{mm})\end{array}$ & 11.94 & 11.92 & 11.93 & 11.95 & 11.92 & 11.94 & 11.94 & 11.92 & 11.92 & 11.92 & 11.92 & 11.93 \\
\hline $\begin{array}{l}\text { Cross- sectional Area } \\
\text { Reduction/Increase } \\
\text { Diameter, } \mathrm{mm})\end{array}$ & 0.05 & 0.05 & 0.05 & 0.05 & 0.05 & 0.05 & 0.05 & 0.05 & 0.05 & 0.05 & 0.05 & 0.05 \\
\hline $\begin{array}{l}\text { Rebar } \quad \text { Weights- } \\
\text { Before Test }(\mathrm{Kg})\end{array}$ & 0.93 & 0.93 & 0.93 & 0.93 & 0.92 & 0.93 & 0.93 & 0.93 & 0.93 & 0.93 & 0.93 & 0.93 \\
\hline $\begin{array}{l}\text { Rebar Weights- After } \\
\text { Corrosion }(\mathrm{Kg})\end{array}$ & 0.87 & 0.87 & 0.87 & 0.87 & 0.87 & 0.87 & 0.88 & 0.88 & 0.87 & 0.87 & 0.87 & 0.88 \\
\hline $\begin{array}{l}\text { Weight Loss /Gain of } \\
\text { Steel }(\mathrm{Kg})\end{array}$ & 0.05 & 0.05 & 0.05 & 0.05 & 0.05 & 0.05 & 0.05 & 0.05 & 0.05 & 0.05 & 0.05 & 0.05 \\
\hline
\end{tabular}

Table 3.3: Potential Ecorr, after 28 days curing and 360days Accelerated Periods of Daniellia oliveri

Exudate / Resin Coated Specimens

\begin{tabular}{|c|c|c|c|c|c|c|c|c|c|c|c|c|}
\hline Sampling and & \multirow{2}{*}{\multicolumn{3}{|c|}{$\begin{array}{l}\text { Samples } 1 \text { (90 days) } \\
\begin{array}{l}150 \mu \mathrm{m} \\
\text { coated }\end{array}\end{array}$}} & \multicolumn{3}{|c|}{ Samples 2 (180 Days) } & \multicolumn{3}{|c|}{ Samples 3 (270 Days) } & \multicolumn{3}{|c|}{ Samples 4 (360 Days) } \\
\hline & & & & $\begin{array}{l}300 \mu \mathrm{m} \\
\text { coated }\end{array}$ & (Exuda & e/Resin) & $\begin{array}{l}450 \mu \mathrm{m} \\
\text { coated }\end{array}$ & (Exuda & e/Resin) & $\begin{array}{l}600 \mu \mathrm{m} \\
\text { coated }\end{array}$ & (Exuda & e/Resin) \\
\hline Potential Ecorr,mV & -127.2 & -126.1 & -125.7 & -125.7 & -122.1 & -126.2 & -124.4 & -128.2 & -124.8 & -119.4 & -119.8 & -117.0 \\
\hline $\begin{array}{l}\text { Concrete Resistivity } \\
\rho, \mathrm{k} \Omega \mathrm{cm}\end{array}$ & 11.64 & 11.79 & 12.07 & 12.20 & 11.89 & 12.18 & 12.13 & 12.28 & 12.31 & 11.78 & 11.67 & 11.52 \\
\hline $\begin{array}{l}\text { Yield Strength, fy } \\
(\mathrm{MPa})\end{array}$ & 454.13 & 453.64 & 451.74 & 447.76 & 446.38 & 449.46 & 449.35 & 447.87 & 449.75 & 450.57 & 451.66 & 451.68 \\
\hline $\begin{array}{l}\text { Ultimate } \quad \text { Tensile } \\
\text { Strength, fu }(\mathrm{MPa})\end{array}$ & 620.79 & 619.74 & 617.42 & 623.20 & 616.73 & 617.15 & 616.95 & 617.75 & 616.35 & 615.90 & 621.40 & 619.26 \\
\hline Strain Ratio & 1.37 & 1.37 & 1.37 & 1.39 & 1.38 & 1.37 & 1.37 & 1.38 & 1.37 & 1.37 & 1.38 & 1.37 \\
\hline $\begin{array}{l}\text { Rebar Diameter } \\
\text { Before Test }(\mathrm{mm})\end{array}$ & 11.99 & 11.97 & 11.98 & 12.00 & 11.97 & 11.99 & 11.99 & 11.97 & 11.98 & 11.98 & 11.97 & 11.98 \\
\hline $\begin{array}{l}\text { Rebar Diameter- } \\
\text { After Corrosion }(\mathrm{mm})\end{array}$ & 12.06 & 12.04 & 12.05 & 12.07 & 12.04 & 12.06 & 12.06 & 12.04 & 12.04 & 12.04 & 12.04 & 12.05 \\
\hline $\begin{array}{l}\text { Cross- sectional } \\
\text { Area } \\
\text { Reduction/Increase } \\
\text { Diameter, mm) } \\
\end{array}$ & 0.06 & 0.06 & 0.06 & 0.06 & 0.06 & 0.06 & 0.06 & 0.06 & 0.06 & 0.06 & 0.06 & 0.06 \\
\hline $\begin{array}{l}\text { Rebar } \quad \text { Weights- } \\
\text { Before Test }(\mathrm{Kg})\end{array}$ & 0.93 & 0.93 & 0.93 & 0.93 & 0.92 & 0.93 & 0.93 & 0.93 & 0.93 & 0.93 & 0.93 & 0.93 \\
\hline $\begin{array}{l}\text { Rebar Weights- After } \\
\text { Corrosion }(\mathrm{Kg})\end{array}$ & 1.00 & 1.00 & 1.00 & 1.00 & 1.00 & 1.00 & 1.00 & 1.00 & 1.00 & 1.00 & 1.00 & 1.00 \\
\hline $\begin{array}{l}\text { Weight Loss /Gain of } \\
\text { Steel (Kg) }\end{array}$ & 0.07 & 0.07 & 0.07 & 0.07 & 0.07 & 0.07 & 0.07 & 0.07 & 0.07 & 0.07 & 0.07 & 0.07 \\
\hline
\end{tabular}


DOI : https://dx.doi.org/10.26808/rs.ed.i11v5.04

International Journal of Emerging Trends in Engineering and Development

Issue 11, Vol.5 (Aug-Sep 2021)

Available online on http://www.rspublication.com/ijeted/ijeted_index.htm

ISSN 2249-6149

Table 3.4: Average Potential Ecorr, after 28 days curing and 360days Accelerated Periods ( Control, Corroded and Exudate/Resin Coated (specimens)

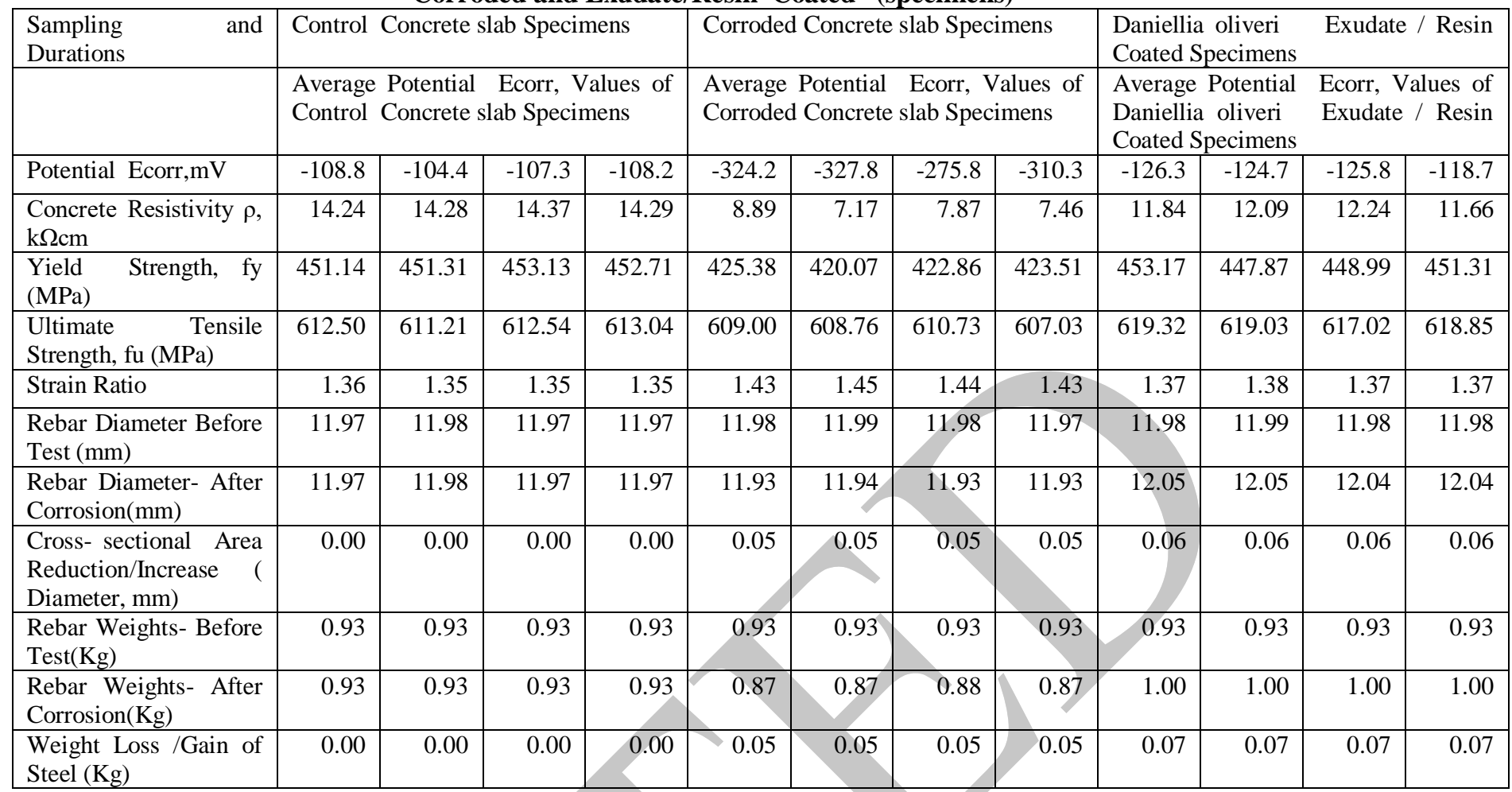

Table 3.5: Average Percentile Potential Ecorr, after 28 days curing and 360days Accelerated Periods (

Control, Corroded and Exudate/Resin Coated (specimens)

\begin{tabular}{|c|c|c|c|c|c|c|c|c|c|c|c|c|}
\hline & \multirow{2}{*}{\multicolumn{4}{|c|}{$\begin{array}{l}\text { Control Concrete slab Specimens } \\
\text { Percentile Average Potential } \\
\text { Ecorr, Values of Control } \\
\text { Concrete slab Specimens }\end{array}$}} & \multirow{2}{*}{\multicolumn{4}{|c|}{$\begin{array}{l}\text { Corroded Concrete slab Specimens } \\
\text { Percentile Average Potential Ecorr, } \\
\text { Values of Corroded Concrete slab } \\
\text { Specimens }\end{array}$}} & \multirow{2}{*}{\multicolumn{4}{|c|}{$\begin{array}{c}\begin{array}{l}\text { Daniellia oliveri Exudate / Resin } \\
\text { Coated Specimens }\end{array} \\
\text { Percentile Average Potential } \\
\text { Ecorr, Values of Daniellia oliveri } \\
\text { Exudate / Resin Coated Specimens }\end{array}$}} \\
\hline & & & & & & & & & & & & \\
\hline Potential Ecorr,mV & -66.43 & -68.15 & -61.10 & -65.12 & 156.59 & 162.90 & 119.26 & 161.24 & -61.03 & -61.96 & -54.39 & -61.72 \\
\hline $\begin{array}{c}\text { Concrete Resistivity } \rho, \\
\mathrm{k} \Omega \mathrm{cm}\end{array}$ & 60.12 & 99.14 & 82.72 & 91.60 & -24.88 & -40.72 & -35.76 & -36.03 & 33.12 & 68.70 & 55.68 & 56.31 \\
\hline Yield Strength, fy (MPa) & 6.06 & 7.44 & 7.16 & 6.89 & -6.13 & -6.21 & -5.82 & -6.16 & 6.53 & 6.62 & 6.18 & 6.56 \\
\hline Ultimate strength $(\mathrm{N} / \mathrm{mm} 2)$ & 0.58 & 0.40 & 0.30 & 0.99 & -1.67 & -1.66 & -1.02 & -1.91 & 1.69 & 1.69 & 1.03 & 1.95 \\
\hline Strain Ratio & -5.17 & -6.56 & -6.37 & -5.51 & 4.75 & 4.85 & 5.09 & 4.52 & -4.54 & -4.62 & -4.85 & -4.33 \\
\hline $\begin{array}{c}\text { Rebar Diameter Before } \\
\text { Test }(\mathrm{mm})\end{array}$ & 0.435 & 0.438 & 0.436 & 0.437 & 0.439 & 0.439 & 0.439 & 0.44 & 0.439 & 0.436 & 0.435 & 0.438 \\
\hline $\begin{array}{c}\text { Rebar Weights- Before } \\
\text { Test }(\mathrm{Kg})\end{array}$ & 0.369 & 0.372 & 0.365 & 0.348 & 0.349 & 0.360 & 0.349 & 0.354 & 0.356 & 0.366 & 0.365 & 0.370 \\
\hline $\begin{array}{l}\text { Rebar Weights- After } \\
\text { Corrosion }(\mathrm{Kg})\end{array}$ & 9.94 & 9.89 & 9.76 & 9.85 & -12.70 & -12.70 & -12.66 & -12.77 & 14.55 & 14.55 & 14.50 & 14.65 \\
\hline $\begin{array}{l}\text { Weight Loss /Gain of Steel } \\
(\mathrm{Kg})\end{array}$ & 0.00 & 0.00 & 0.00 & 0.00 & -26.03 & -26.03 & -26.03 & -26.03 & 35.19 & 35.19 & 35.19 & 35.19 \\
\hline
\end{tabular}




\section{Results of Potential $\mathrm{E}_{\text {corr }}, \mathrm{mV}$, and Concrete Resistivity $\rho, \mathrm{k} \Omega \mathrm{cm}$ on Concrete Slab Members}

Electrical resistivity is considered a reliable indicator of a corrosive environment, including concrete subjected to chloride penetration. Detection of chlorides in concrete using electrical resistivity, such as electrical resistivity correlates with chloride transport, as well as with how electrical resistivity can serve as an aid in calculating and predicting the diffusion coefficient of concrete.

The durability of concrete structures is determined by the requirements for strength levels, fluid transport properties, exposure conditions, and the geometry of the concrete cover (layer depth and diameter of reinforcing steel). It is assumed that meeting these requirements will ensure an adequate service life, although the exact effect and quantification of its impact on service life are not well known and studied ([37]). As obtained from Tables 3.1 - 3.3 and summarized in Tables 3.4 and 3.5 for average and percentile values, in Figure 3.1-3.7b the results of controlled, uncoated (corroded) and coated samples for 36 concrete slabs, divided into 3 sets of 12 controlled samples representing the determining reference range, 12 uncoated (corroded) samples and 12 exudates/resin-coated samples.

The average and minimum, maximum, and differential values of the calculated measurements of the half-cell potential of the controlled sample were $-108.86 \mathrm{mV}$ and $-104.43 \mathrm{mV}(68.15 \%$ and $-61.1 \%$ ) with a potential differential of $4.43 \mathrm{mV}$ and $7.05 \%$ ), the corroded samples were $327.86 \mathrm{mV}$ and $-275.86 \mathrm{mV}(119.26 \%$ and $162.9 \%)$ and the differential values were $52 \mathrm{mV}$ and $43.64 \%$, and the coated samples were $-126.38 \mathrm{mV}$ and $-118.79 \mathrm{mV}(-61.96 \%$ and $-54.39 \%)$ and the potential differential is $7.59 \mathrm{mV}$ and $7.57 \%$, respectively. The maximum calculated controlled percentile was $-61.1 \%$ compared to the corroded and coated values of $162 \%$ and $54.39 \%$ and the controlled differential potential value was $7.05 \%$, corroded $43.64 \%$, and coated $7.57 \%$.

The maximum computed values of the controlled and coated samples were $-104.43 \mathrm{mV}$ and $118.79 \mathrm{mV}$, which showed the relationship between corrosion potential and opportunity in the reference range $E$ corr $>-200 \mathrm{mV}$. The results from this potential Ecorr result show that the values of controlled samples and exudate/resin coated samples are low, with a 90\% probability that the reinforcement in this area will not corrode during measurement $(10 \%$ risk of corrosion). The maximum calculated value of corroded is $-275.86 \mathrm{mV}$, the result is of the reference value of the relationship between corrosion potential and probability of $-350 \mathrm{mV} \leq$ $E$ corr $\leq-200 \mathrm{mV}$ indicates a high-value range of $10 \%$ or an uncertain corrosion probability. The reference range indicates that corroded sample shows corrosion attack on reinforcing steel embedded in concrete as a result of accelerated induced corrosion compared to coated samples showing no corrosion. Plates are exposed to a corrosive environment due to the formation of a resistive layer.

The average value and the minimum and maximum percentile of concrete resistivity with a controlled sample potential differential were $14.24 \mathrm{k} \Omega \mathrm{cm}$ and $14.37 \mathrm{k} \Omega \mathrm{cm}(60.12 \%$ and $99.14 \%$ ), and the differential values were $0.13 \mathrm{k} \Omega \mathrm{cm}$ and $39.02 \%$, respectively. The samples were $7.17 \mathrm{k} \Omega \mathrm{cm}$ and $8.89 \mathrm{k} \Omega \mathrm{cm}(-40.72 \%$ and $-24.88 \%)$ and the differential values were $1.72 \mathrm{k} \Omega \mathrm{cm}$ and $15.84 \%$, the coated sample wells were $11.66 \mathrm{k} \Omega \mathrm{cm}$ and $12.24 \mathrm{k} \Omega \mathrm{cm}(33.12 \%$ and $68.7 \%$ ) and the differential values of $0.58 \mathrm{mV}$ and $35.58 \%$, respectively.

The maximum value calculated from the resistivity of the controlled sample concrete is 99.14\% compared to the corroded and coated values of $-24.88 \%$ and $68.7 \%$ and the maximum value of the control percentile differential is $39.02 \%$ compared to the corroded and coated value by $15.84 \%$ and $35.58 \%$. The results of the controlled and coated concrete resistivity samples obtained a maximum average value of $14.37 \mathrm{k} \Omega \mathrm{cm}$ and $12.24 \mathrm{k} \Omega \mathrm{cm}$ with a description of the value $10<\rho<20$ (low) compared to the corrosion value of $8.89 \mathrm{k} \Omega \mathrm{cm}$ with specifications $5<\rho<10$ (high) and with a reference range of dependence between concrete 
resistivity and corrosion probability significant corrosion probability $(\rho<5,5<\rho<10,10<$ $\rho<20, \rho>20$ ) or very high, high, low to medium and low, for possible corrosion. From the comparison results of coated and corroded samples, the maximum values obtained for both samples indicate the value of coated samples with a range of $10<\rho<20$, which classifies the range of values as low to moderate, with information as significant corrosion probability. The maximum value of the corroded sample was in the range of $5<\rho<10$, indicating high, signs indicating the presence of possible corrosion, confirmed in the studies of ([20],[21],[25],[28]). From the results obtained, it can be compared that the effect of corrosion attack was observed in uncoated samples, while samples with exudate/resin coating had anti-corrosion properties with highly resistant and water-resistant membranes that prevented corrosion of concrete reinforcement exposed to the induced accelerated corrosion media.

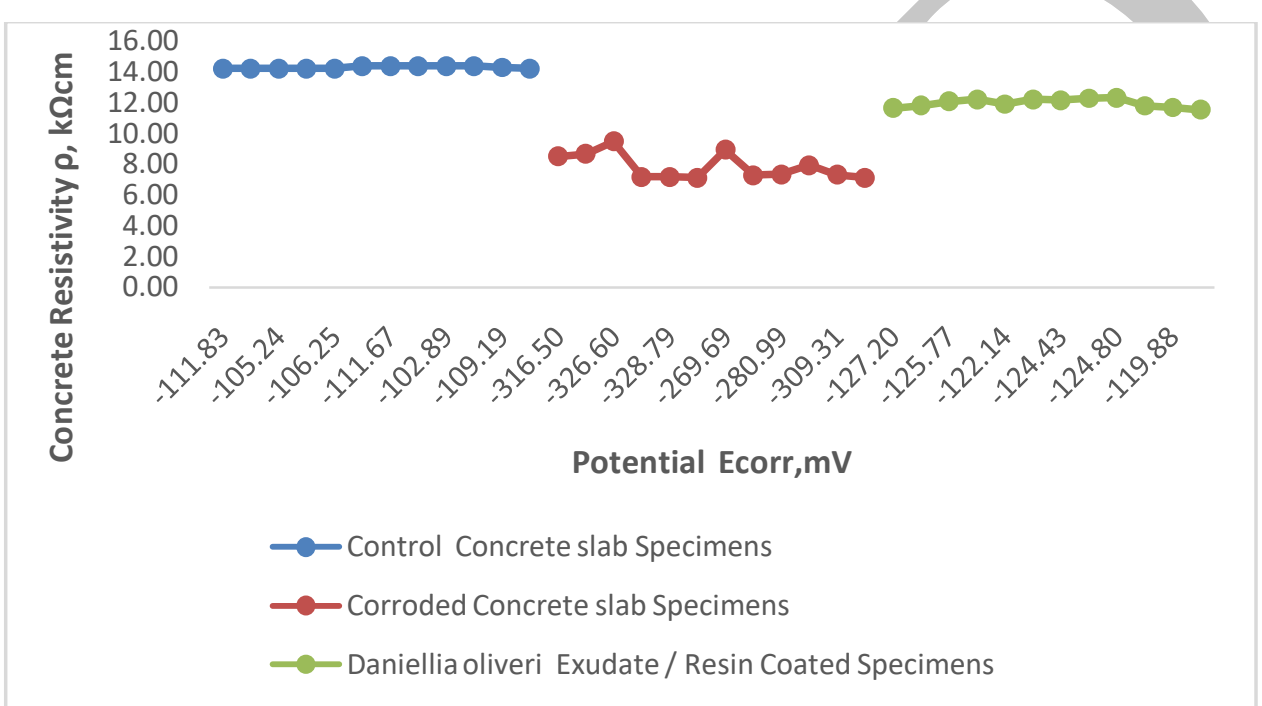

Figure 3.1 : Concrete Resistivity $\rho, \mathrm{k} \Omega \mathrm{cm}$ versus Potential Ecorr,mV Relationship

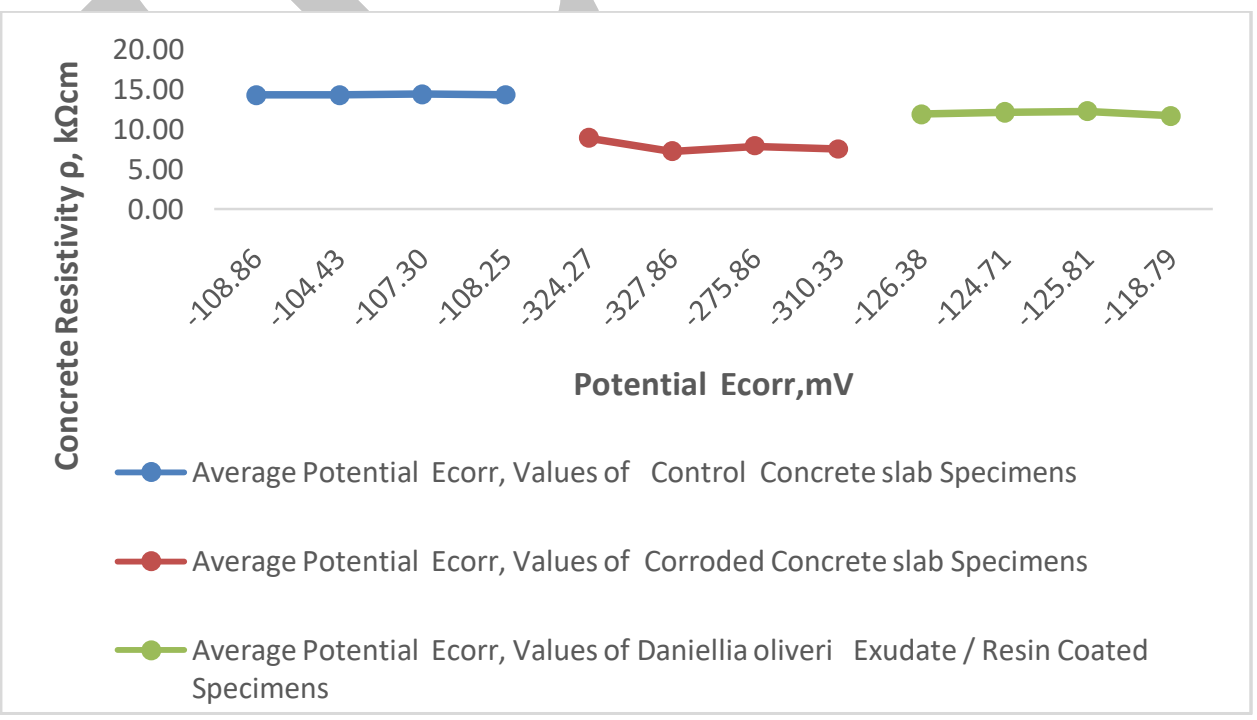

Figure 3.1A: Average Concrete Resistivity versus Potential Relationship 


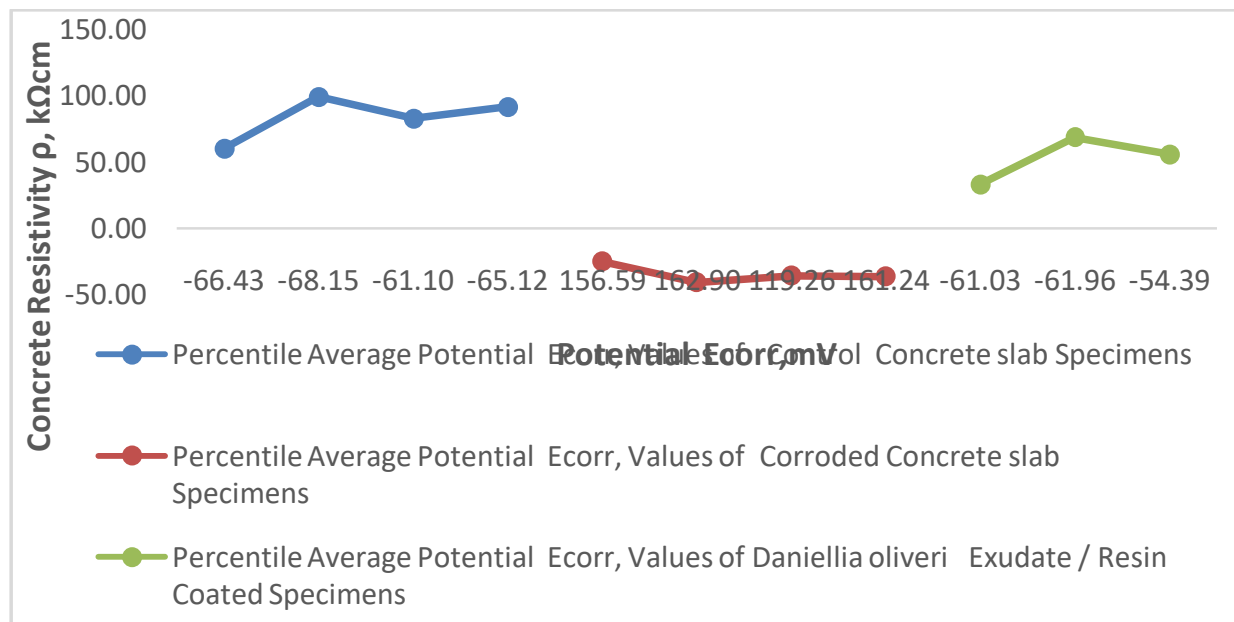

Figure 3.1B : Average Percentile Concrete Resistivity versus Potential Relationship

\section{Results of Mechanical Properties of Yield Strength, Ultimate Strength and Strain Ratio of Embedded Reinforcing Steel in Concrete Slab}

Corrosion of reinforcing steel embedded in reinforced concrete structures causes a reduction in the diameter of steel reinforcement, resulting in reduced mechanical properties such as tensile strength, tensile strength and ductility. Therefore, the corrosion products occupy a much larger volume than the original steel and in the end exert a large tensile force on the surrounding concrete, which causes cracking and falling of the concrete roof and loss of bonding strength between steel and concrete. The results of the average, percentile, and the differential between the minimum and maximum yield strength, fy (MPa) of the controlled sample were $451.14 \mathrm{MPa}$ and $453.13 \mathrm{MPa}(6.06 \%$ and $7.44 \%)$, and the differential value was $1.99 \mathrm{MPa}$ and $1.38 \%$, the corroded samples were $420.07 \mathrm{MPa}$ and $425.38 \mathrm{MPa}(-6.21 \%$ and $5.82 \%$ ) and the differential values were $5.31 \mathrm{MPa}$ and $0.39 \%$, the coated sample values were $447.87 \mathrm{MPa}$ and $453.17 \mathrm{MPa}(6.18 \%$ and $6.62 \%)$ and the differential value is $5.3 \mathrm{MPa}$ and $0.44 \%$. The calculated maximum percentile value of the controlled yield strength was $7.44 \%$ compared to the corroded and coated values $-5.82 \%$ and $6.62 \%$ and the possible differential values were $1.38 \%$ controlled, $0.39 \%$ corroded and $0.44 \%$ coated.

The average, percentile, and the differential between the minimum and maximum ultimate tensile strength, fu (MPa) of the controlled sample were $611.21 \mathrm{MPa}$ and $613.04 \mathrm{MPa}(0.3 \%$ and $0.99 \%$ ) and the differential value was $1.83 \mathrm{MPa}$ and $0.69 \%$, corroded $607.03 \mathrm{MPa}$ and $610.73 \mathrm{MPa}(-1.91 \mathrm{MPa}$ and $-1.02 \%)$ and a differential of $3.7 \mathrm{MPa}$ and $0.89 \%$, the coated values are $617.02 \mathrm{MPa}$ and $619.32 \mathrm{MPa}(10.03 \%$ and $1.95 \%$ and the differential value is 2.3MPa. The ultimate tensile strength maximum calculated percentile of the controlled tensile strength is $0.99 \%$ relative to corroded and the coated value is $-1.02 \%$ and $1.95 \%$ respectively and the potential differential value $0.69 \%$ controlled, $0.89 \%$ corroded and $0.92 \%$ coated.

The minimum and maximum average values of the strain ratio, percentile and differential values of the controlled samples were 1.35 and $1.36(-6.56 \%$ and $-5.17 \%)$ with a differential value of 0.01 and $1.39 \%$, respectively. the corroded values of the samples were 1.43 and 1.45 $(4.52 \%$ and $5.09 \%)$ and the differential values were 0.02 and $0.57 \%$, the coated samples were 1.37 and $1.38(-4.85 \%$ and $-4.33 \%)$ and the differential value of $0.01 \%$ and $0.52 \%$. The strain ratio maximum percentile value calculated for comparison was checked $-5.17 \%$ versus corroded $-5.09 \%$ and value $-4.33 \%$, and different peak values checked $1.39 \%$, corroded $0.57 \%$ and coated $0.52 \%$ as confirmed in studies ([20],[21],[25],[28]). 
The calculated results, which are summarized in Tables 3.4 and 3.5 and shown graphically in Figures 3.1 - 3.8, were used to determine the yield strength, ultimate tensile strength and strain ratio of the average, percentile and differential potential values of the control, corroded and coated, coated samples reported higher failure loads applications compared to corroded samples with reduced failure loads and low load bearing capacities and with average and percentile values to the reference range, while uncoated low loads (corroded) - carrying capacity and reduced value compared to the reference range. The comparison results show that the low load carrying capacity is caused by the effect of corrosion attack on the uncoated (corroded) samples, which interfere with reinforcing steel fibers, ribs and passive formation and surface modification. The observed average values for the coated samples were traced back to the potential for corrosion resistivity to penetrate the reinforcing steel with the formation of a protective membrane; these attributes indicate the effectiveness and effectiveness of exudates / resins as inhibitors against the corrosion effects of reinforced concrete structures, heavy marine areas with high salt content are exposed.

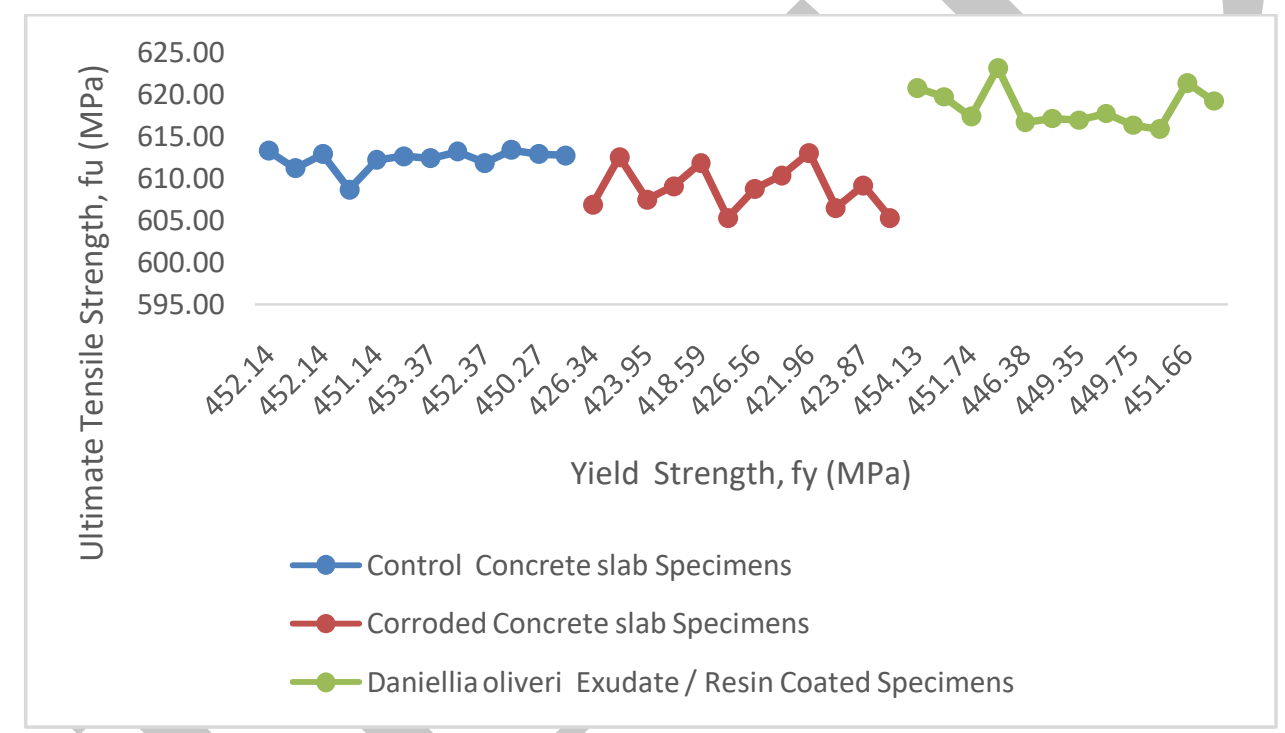

Figure 3.2: Yield Strength versus Ultimate strength

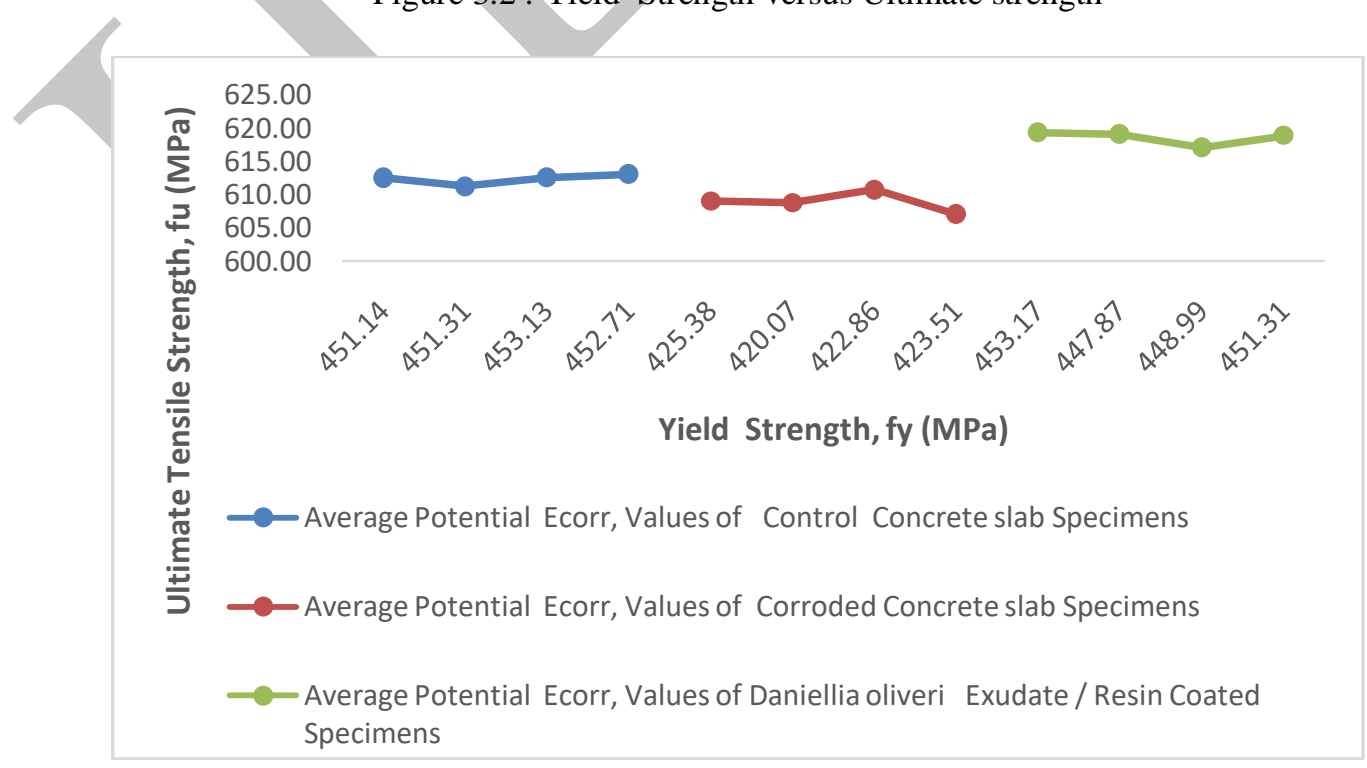

Figure 3.2A: Average Yield Strength versus Ultimate Tensile Strength 
DOI : https://dx.doi.org/10.26808/rs.ed.i11v5.04

International Journal of Emerging Trends in Engineering and Development

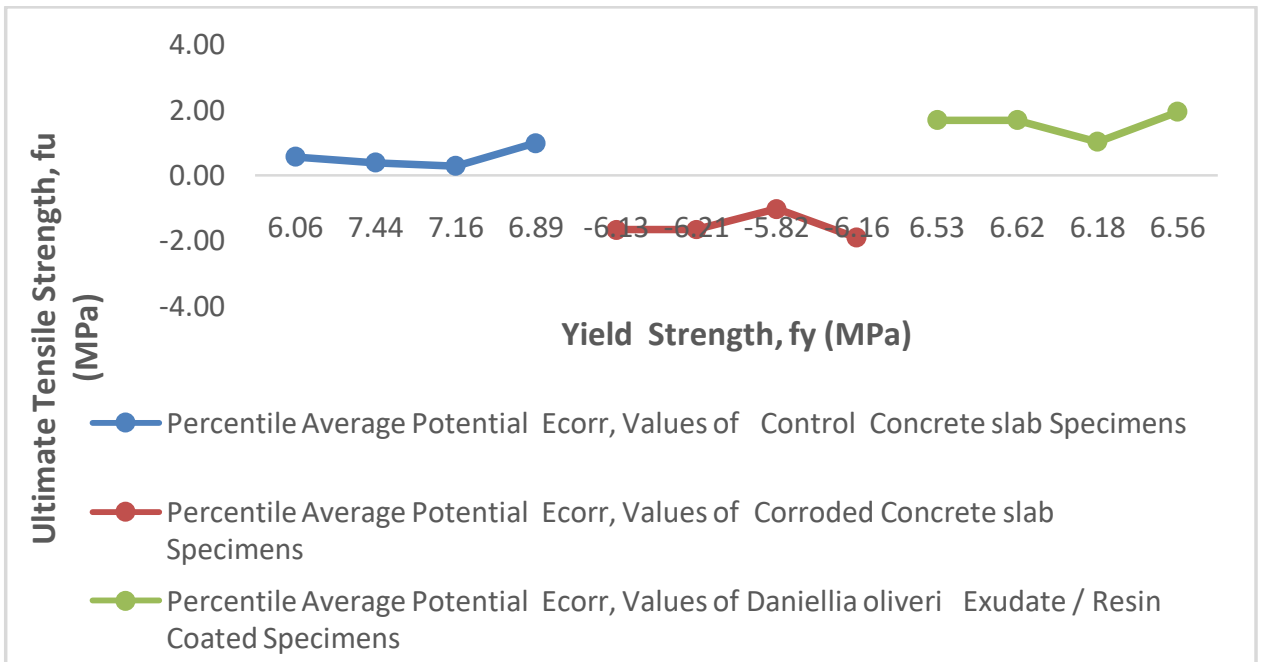

Figure 3.2B: Average Percentile Yield Strength versus Ultimate Tensile Strength

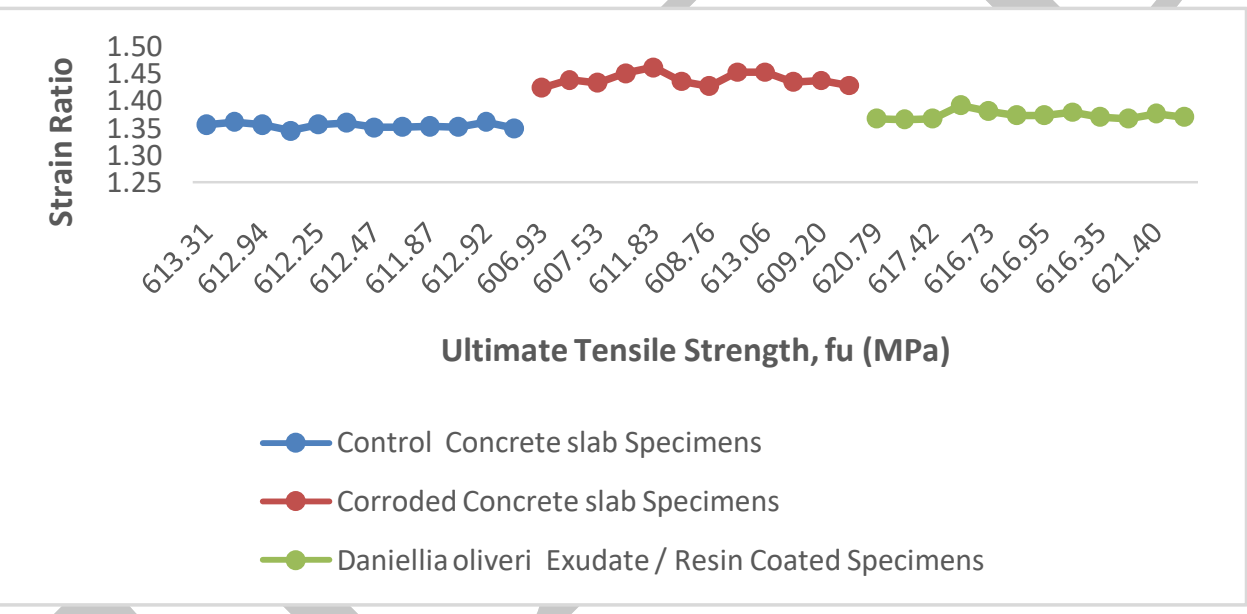

Figure 3.3: Ultimate Tensile Strength versus Strain Ratio

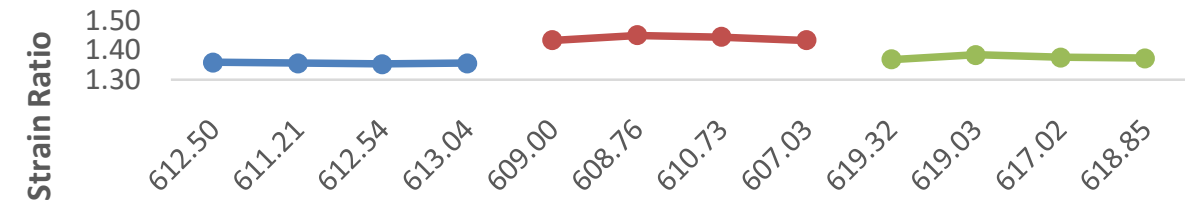

Ultimate Tensile Strength, fu (MPa)

-Average Potential Ecorr, Values of Control Concrete slab Specimens

-Average Potential Ecorr, Values of Corroded Concrete slab Specimens

-Average Potential Ecorr, Values of Daniellia oliveri Exudate / Resin Coated Specimens

Figure 3.3A: Average Ultimate Tensile Strength versus Strain Ratio 


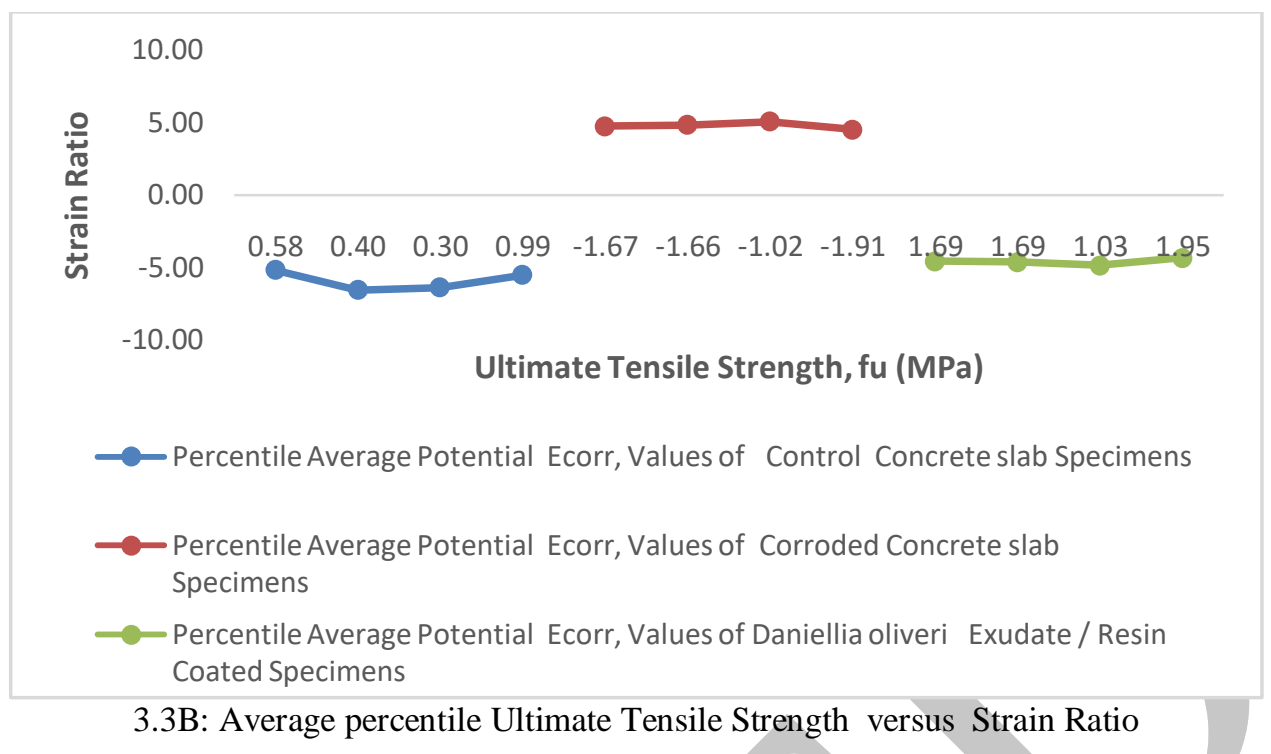

\section{Results of Mechanical Properties of Rebar Diameter, Cross-Sectional Area and Weight Loss / Increase of Embedded Reinforcing Steel in Concrete Slab}

The radius loss of reinforcing steel that causes concrete cracking is referred to as the critical amount of corrosion product, which in most literature is also known as critical attack penetration $(\delta \mathrm{r})$. With regard to the corrosion effect of reinforcement on concrete, the formation of cracks in the concrete cover is the most important indicator of the end of life of reinforced concrete structures. Crack closure time is a significant index of the intensity of the corrosive environment to which reinforced concrete elements are exposed. Rebar diameter before testing $(\mathrm{mm})$ the average value and the percentile of the minimum and maximum controlled $11.97 \mathrm{~mm}$ and $11.98 \mathrm{~mm}(0.435 \%$ and $0.438 \%)$ with a differential of $0.01 \mathrm{~mm}$ and $0.003 \%$, the corrosion value of the sample is $11.97 \mathrm{~mm}$ and $11.99 \mathrm{~mm}(0.439 \%$ and $0.44 \%)$ and the differential values of $0.02 \mathrm{~mm}$ and $0.001 \%$ and the values of the coated samples were $11.98 \mathrm{~mm}$ and $11.99 \mathrm{~mm}(0.435 \%$ and $0.439 \%$ and the values that were calculated differentially $0.01 \mathrm{~mm}$ and $0.004 \%$. The weight of the pieces of reinforcement before the corrosion test shows a small differential based on the products and company form, as well as by-products used in the production process, the average value, percentile, and differential in diameter of the reinforcement after corrosion $(\mathrm{mm})$ for controlled samples, were $11.97 \mathrm{~mm}$ and $11.98 \mathrm{~mm}(0.435 \%$ and $0.438 \%)$ respectively. The differential in values was $0.01 \mathrm{~mm}$ and $0.003 \%$, the corroded value was $100 \%$ and, the corroded sample value was $11.93 \mathrm{~mm}$ and $11.94 \mathrm{~mm}(-0.996 \%$ and $-0.899 \%)$ and a differential of $0.01 \mathrm{~mm}$ and $0.097 \%$, the coated sample values were $12.04 \mathrm{~mm}$ and $12.05 \mathrm{~mm}(0.986 \%$ and $1.096 \%)$ and the differential between $0.01 \mathrm{~mm}$ and $0.11 \%$. The maximum calculated percentile was controlled to be $0.438 \%$ versus $-0.899 \%$ corroded and $1.096 \%$ coated, with different percentile corrosion $0.097 \%$ versus $0.11 \%$ coated. The results obtained in Tables 3.4 and 3.5, which are summarized in Tables 3.1, 3.2, and 3.3 and shown graphically in Figures 3.3-3.6b, show the effect of corrosion attack on reinforcing steel embedded in the concrete slab, which is exposed to induced corrosion-accelerating activity. For comparison, the results of the corroded samples showed a reduction and reduction value compared to the diameter of the reinforcement before and after the induction accelerated corrosion test with a percentile decrease in value from $0.438 \%$ to $-0.899 \%$ and an average value in the range from $11.98 \mathrm{~mm}$ to $11.93 \mathrm{~mm}$.

The decrease/increase (diameter) in cross-sectional area minimum and maximum average and percentile values controlled to $100 \%$ without notice of reduction or increase after 360 days of 
freshwater immersion. Corrosion sample values were $0.05 \mathrm{~mm}$ and $0.05 \mathrm{~mm}(-22.47 \%$ and $20.77 \%$ ) and the differential was $0.00 \mathrm{~mm}$ and $1.7 \%$ for corroded, coated sample values were $0.06 \mathrm{~mm}$ and $0.06 \mathrm{~mm}(24.58 \%$ and $26.61 \%)$ and a differential of $0.00 \mathrm{~mm}$ and $2.03 \%$. The cross-sectional area relative average and differential in percentile values between coated and corroded samples ranged from $26.61 \%$ to $-20.77 \%$. The decrease in average and percentile values indicated that the corrosion effect led to a reduction in diameter and cross-sectional area, fiber degradation, rib reduction, and surface modification, whereas elements coated with exudate/resin confirmed an increase in volume as the layer thickness differential as validated in the studies of ([20],[21],[25],[28]). In summary, it can be said that the exudate/resin has inhibitory properties against corrosive effects on reinforcing steel embedded in the concrete slab sample, which is induced in an environment with high salt content.

There rebar unit "Weight - Before Test" $(\mathrm{Kg})$ minimum, maximum and differential average and percentile of controlled samples were $0.93 \mathrm{~kg}$ and $0.93 \mathrm{~kg}(0.348 \%$ and $0.372 \%)$ and the differential was $0.00 \%$ and $0.024 \%$, corroded samples $0.93 \mathrm{~kg}$ and $0.93 \mathrm{~kg} 0.349 \%$ and $0.36 \%$ ) and the differential between $0.00 \%$ and $0.011 \%$, coated samples $0.93 \mathrm{~kg}$ and $0.93 \mathrm{~kg}$ $(0.356 \%$ and $0.37 \%)$, with a differential of $0.00 \%$ and $0.014 \%$.

The average and percentile weight of rebar unit weight after corrosion $(\mathrm{Kg})$ and the aggregate differential values of the minimum and maximum values of the controlled samples were 0.93 $\mathrm{kg}$ and $0.93(0.00 \%$ and $0.00 \%)$ and the differential was $0.00 \%$ and $0.00 \%$, the corroded samples were $0.87 \mathrm{~kg}$ and $0.88 \mathrm{~kg}(-12.77 \%$ and $-12.66 \%)$ and a differential of $0.01 \%$ and $0.11 \%$, the values of the coated samples were $0.965 \mathrm{~kg}$ and $0.965 \mathrm{~kg}(14.5 \%$ and $14.65 \%)$ and the differential was $0.01 \%$ and $0.15 \%$. Average and percentile loss/gain of minimum and maximum units weight of steel $(\mathrm{Kg})$ and percentile differential in comparison controlled as a result of aggregation in freshwater tanks with no trace of corrosion potential relative to the corroded sample, values maintained at $100 \%$ value $0.05 \mathrm{~kg}$ and $0.05 \mathrm{~kg}(-26.03 \%$ and $26.03 \%)$ and coverage of $0.07 \mathrm{~kg}$ and $0.07 \mathrm{~kg}(35.19 \%$ and $35.19 \%)$. The calculation results from Tables 3.1-3.3 and in 3.4 - 3.5 are summarized and plotted graphically in Figures 3.7$3.7 \mathrm{~B}$, listing the effects of corrosion on uncoated (corroded) and coated reinforcing steel and checking the weight of the pieces of reinforcement before and after testing for corrosion and settlement. /weight gain. For comparison, the results obtained show a reduction of rebar unit weight after corrosion in the average and percentile values for coated from $0.965 \mathrm{~kg}$ to $0.877 \mathrm{~kg}$ and corrosion $14.65 \%$ to $-12.66 \%$, as in the studies of ([20],[21],[25],[28]). The combined results show that the corrosion effect on the corroded samples causes a decrease/decrease in weight compared to coatings with percentile loading and an increase in average values, which causes a slight increase in volume with coating thickness. This study shows the efficacy and effectiveness of exudate/resin as an inhibitor against the effects of corrosion on reinforcement embedded in samples of concrete slabs exposed to induced corrosion.

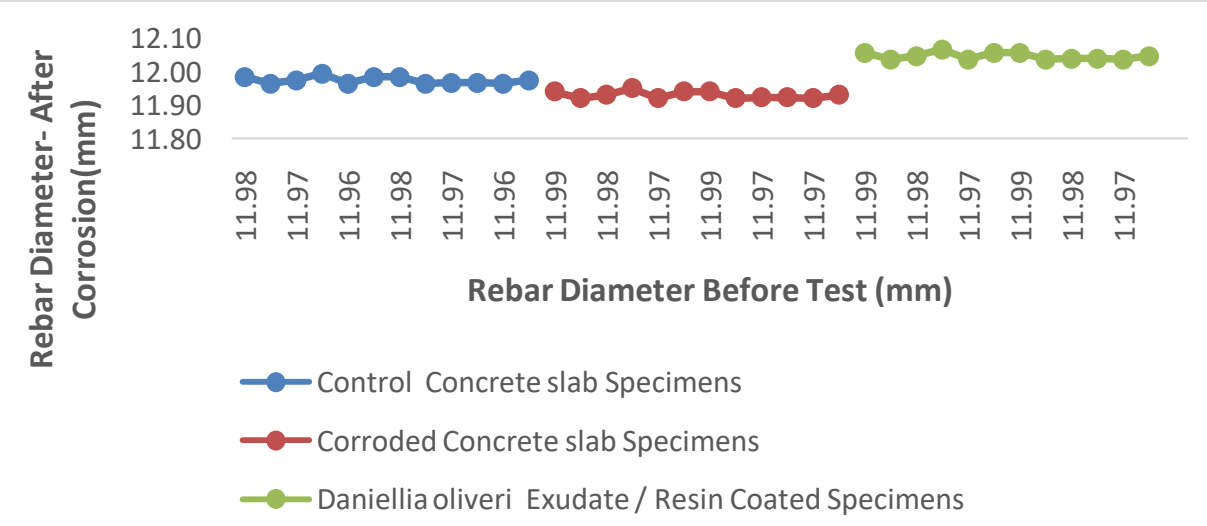

Figure 3.4: Rebar Diameter Before Test(mm) versus Rebar Diameter- After Corrosion(mm) 
DOI : https://dx.doi.org/10.26808/rs.ed.i11v5.04

International Journal of Emerging Trends in Engineering and Development

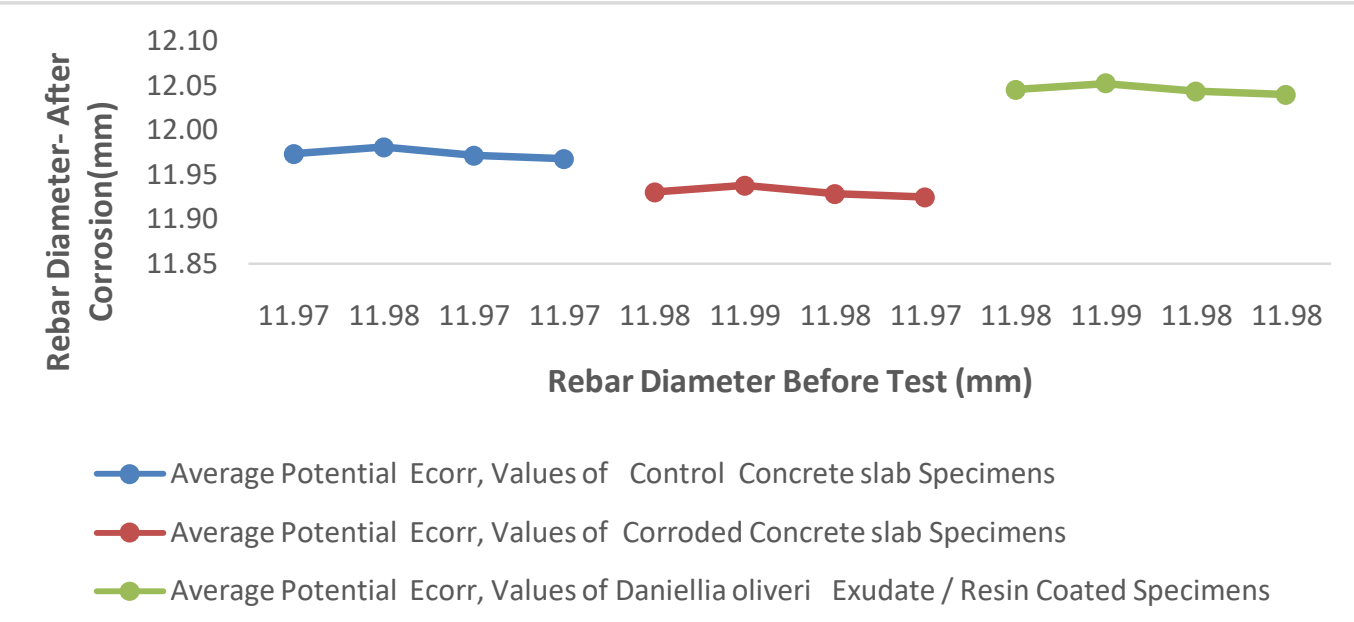

Figure 3.4A: Average Rebar Diameter Before Test(mm) versus Rebar Diameter- After Corrosion(mm)

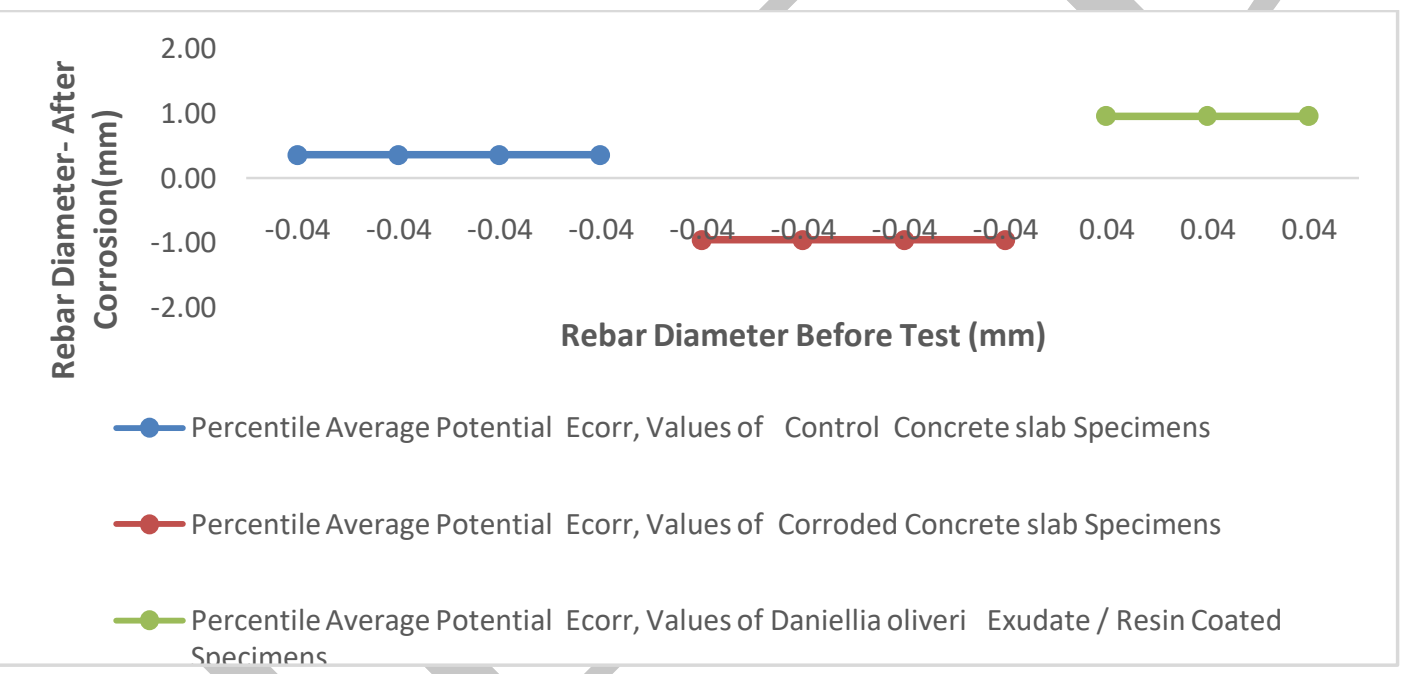

Figure 3.4B: Average Percentile Rebar Diameter Before Test $(\mathrm{mm})$ versus Rebar Diameter- After Corrosion(mm)

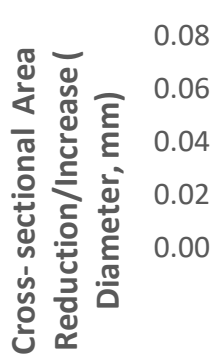

の సે

Rebar Diameter-After Corrosion(mm)

-Control Concrete slab Specimens

-Corroded Concrete slab Specimens

-Daniellia oliveri Exudate / Resin Coated Specimens

Figure 3.5: Rebar Diameter- After Corrosion(mm) versus Cross- section Area Reduction/Increase ( Diameter, $\mathrm{mm}$ 
DOI : https://dx.doi.org/10.26808/rs.ed.i11v5.04

International Journal of Emerging Trends in Engineering and Development

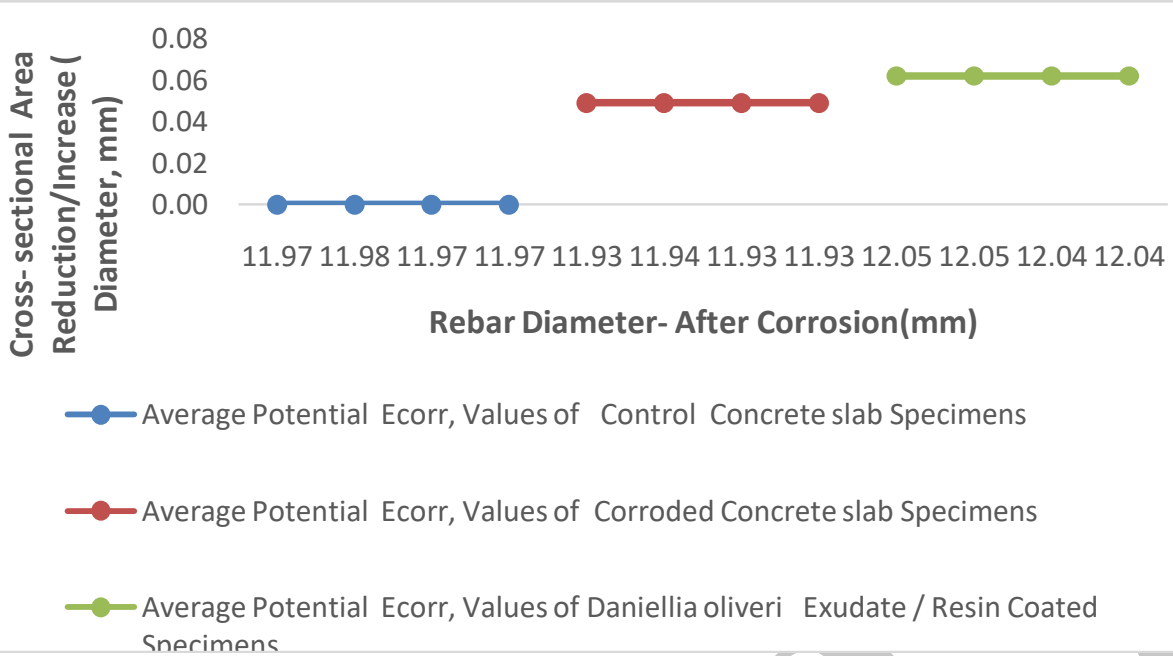

Figure 3.5A: Average Rebar Diameter- After Corrosion(mm) versus Cross- section Area Reduction/Increase ( Diameter, $\mathrm{mm}$ )

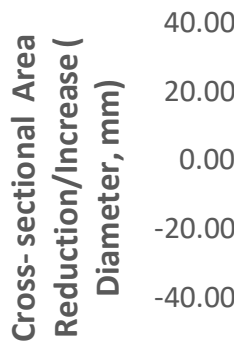

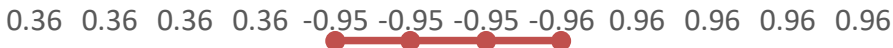

Rebar Diameter- After Corrosion(mm)

$\longrightarrow$ Percentile Average Potential Ecorr, Values of Control Concrete slab Specimens

-Percentile Average Potential Ecorr, Values of Corroded Concrete slab Specimens

-Percentile Average Potential Ecorr, Values of Daniellia oliveri Exudate / Resin Coated Snerimens

Figure 3.5B: Average Percentile Rebar Diameter- After Corrosion(mm) versus Cross- section Area Reduction/Increase ( Diameter, $\mathrm{mm}$ )

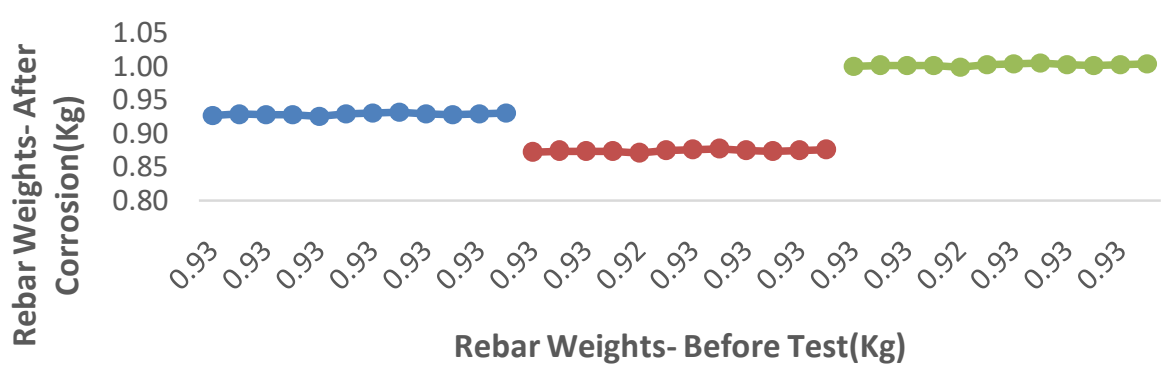

$\longrightarrow$ Control Concrete slab Specimens

-Corroded Concrete slab Specimens

-Daniellia oliveri Exudate / Resin Coated Specimens

Figure 3.6: Rebar Weights- Before Test $(\mathrm{Kg})$ versus Rebar Weights- After Corrosion(Kg) 
DOI : https://dx.doi.org/10.26808/rs.ed.i11v5.04

International Journal of Emerging Trends in Engineering and Development

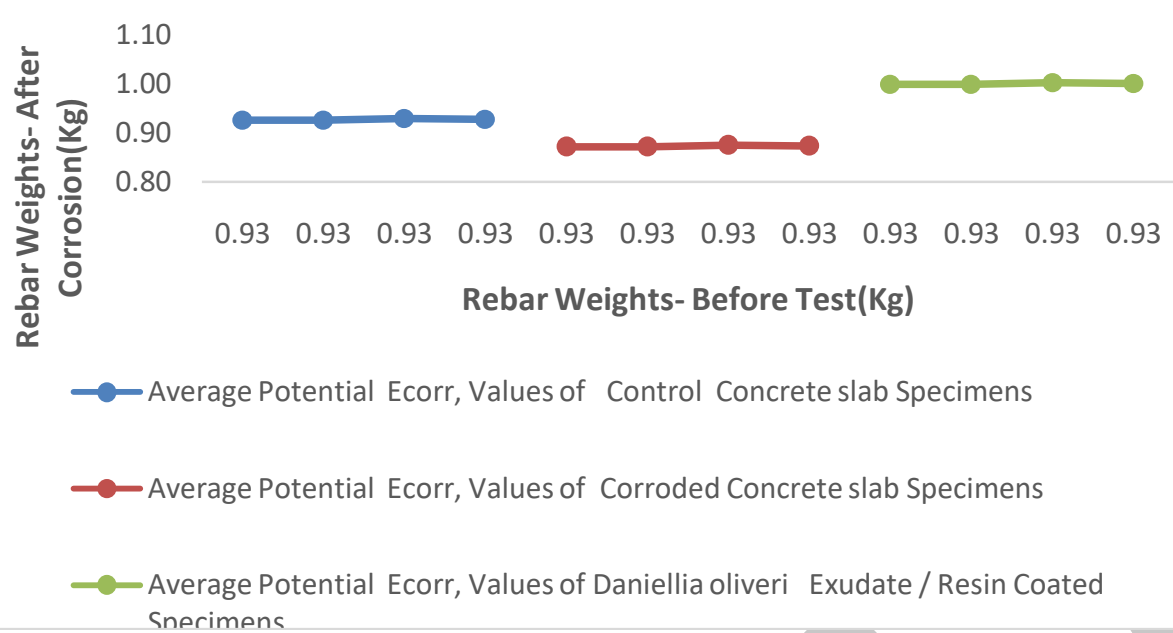

Figure 3.6A: Average Rebar Weights- Before Test $(\mathrm{Kg})$ versus Rebar Weights- After Corrosion(Kg)

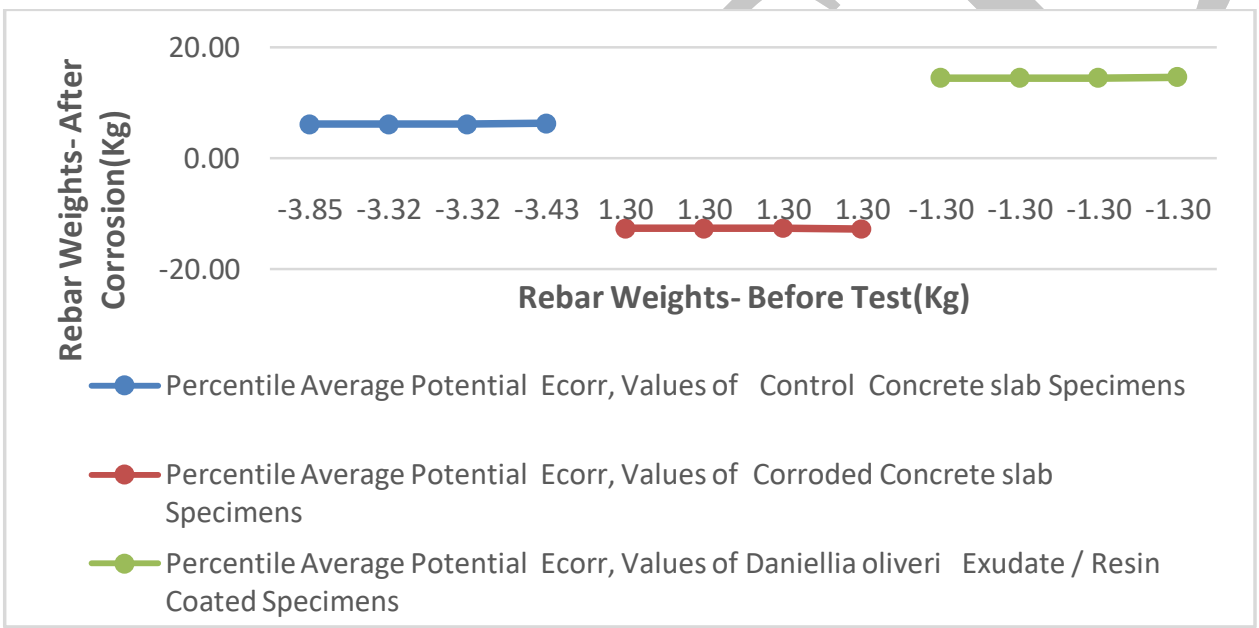

Figure 3.6B: Average Percentile Rebar Weights- Before Test $(\mathrm{Kg})$ versus Rebar Weights- After Corrosion(Kg)

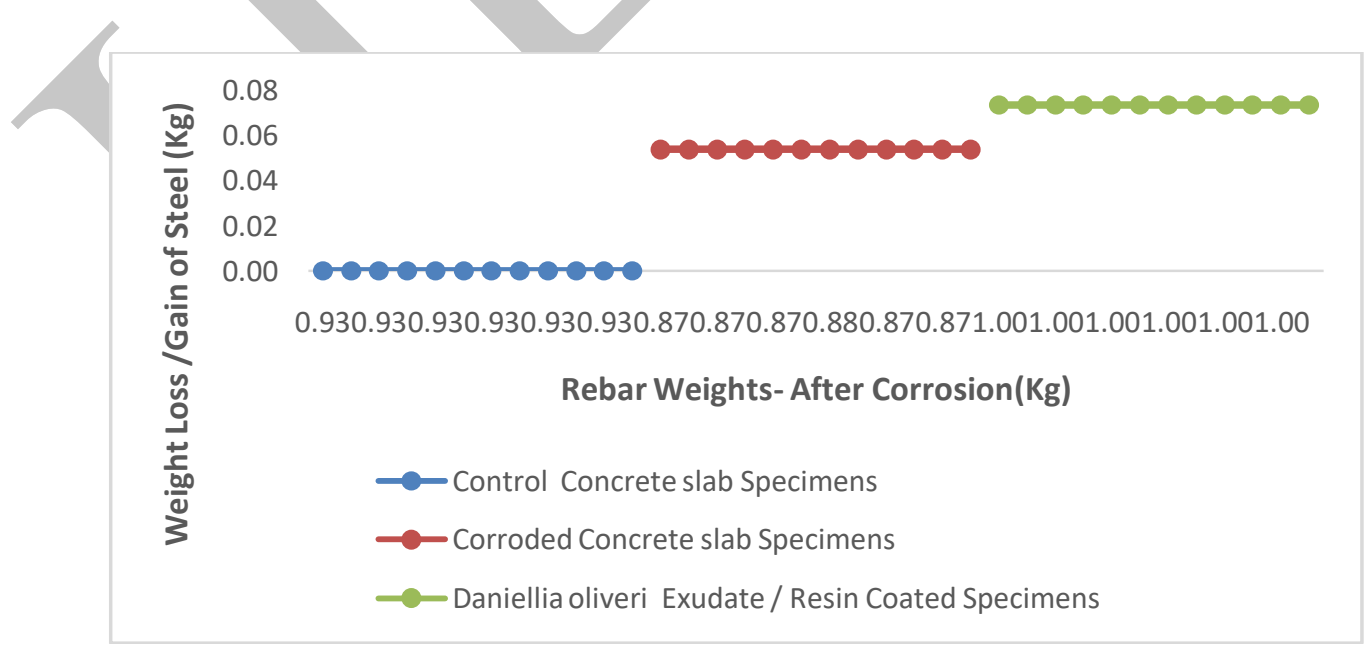

Figure 3.7: Rebar Weights- After Corrosion $(\mathrm{Kg})$ versus

Weight Loss /Gain of Steel (Kg) 


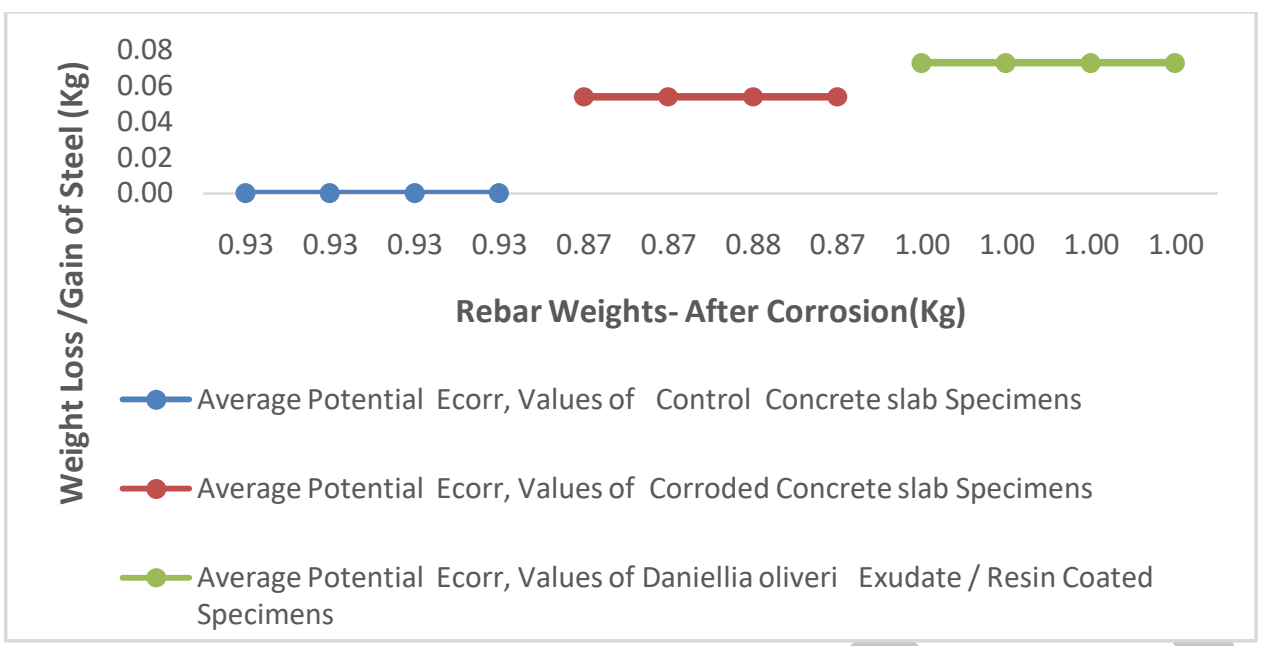

Figure 3.7A: Average Rebar Weights- After Corrosion(Kg) versus Weight Loss /Gain of Steel $(\mathrm{Kg})$

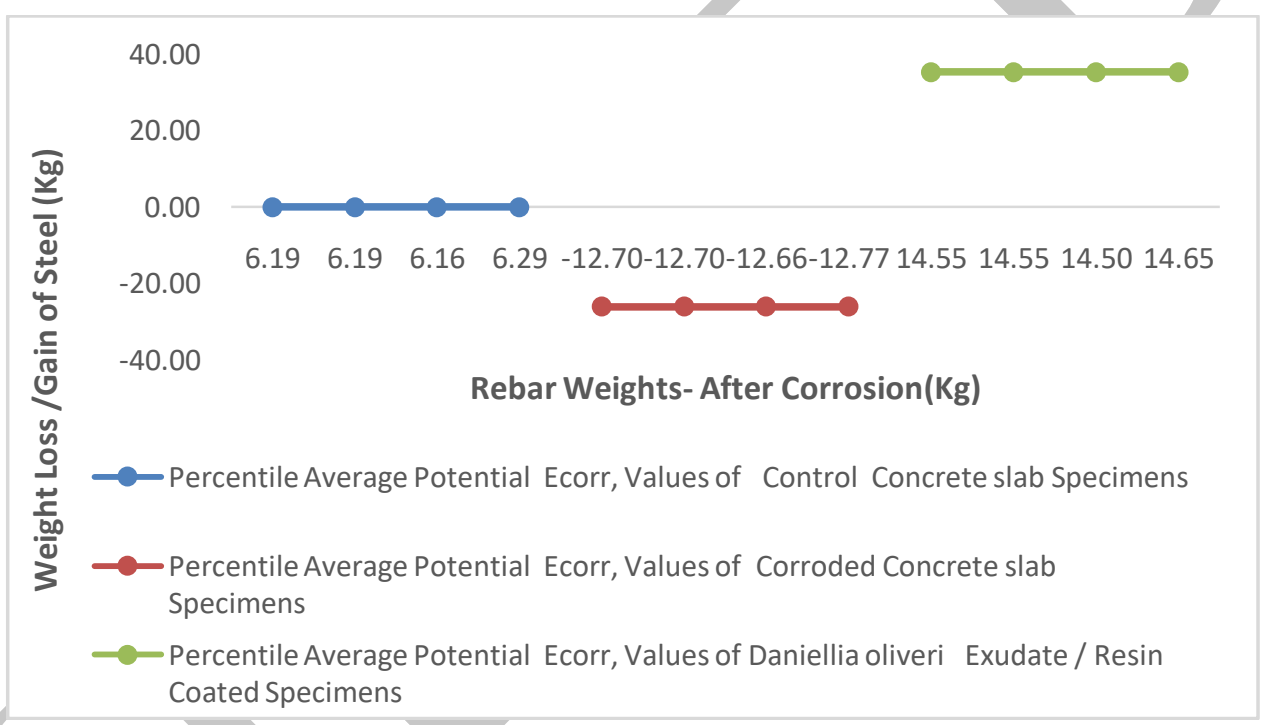

Figure 3.7B: Average Percentile Rebar Weights- After Corrosion(Kg) versus

\subsection{CONCLUSION}

$$
\text { Weight Loss /Gain of Steel (Kg) }
$$

Experimental results showed the following conclusions:

i. Coated reinforcing steel showed no indications of corrosion presence

ii. Daniellia oliveri exudates / resins showed an inhibitory properties against corrosion attacks

iii. Reduction in diameter and cross-sectional areas were noticed in corroded samples

iv. Weight loss was witnessed in corroded samples while inhibited samples exhibited minute volumetric increase.

v. Yield strength and ultimate tensile strength reduction was noticed in corroded samples resulting from corrosion effect

\section{REFERENCES}

1. Broomfield, J. P. (2007). Corrosion of steel in concrete: understanding, investigation and repair (Second ed.). UK: Taylor and Francis.

2. Morris, W., Vico, A., and Vázquez, M. (2004). Chloride induced corrosion of reinforcing steel evaluated by concrete resistivity measurements. Electrochimica Acta, 49(25): 44474453. 
3. Page, C. L., and Page, M. M. (2007). Durability of concrete and cement composites: Elsevier.

4. Poulsen, E. (1995). Chloride profiles-Analysis and interpretation of observations. AEClaboratory, Vadbaek.

5. Bertolini, L., Elsener, B., Pedeferri, P., Redaelli, E., and Polder, R. B. (2013). Corrosion of steel in concrete: prevention, diagnosis, repair (Second ed.). Germany: John Wiley and Sons.

6. Uhlig, H. (2004). Corrosion and Control, George Harrap and Co. Ltd.

7. Moretti G., Guidi, F. \& Grion, G. (2004). Tryptamine as a green iron corrosion inhibitor in $0.5 \mathrm{M}$ deaerated sulphuric acid. Corrosion Sci., 46 (2): 387-403.

8. El-Etre, A.Y. (2003). Inhibition of aluminum corrosion using Opuntia extract. Corrosion Sci.,45(11): 2485-2495

9. El-Etre, A. Y. (2006). Khillah extract as inhibitor for acid corrosion of SX 316 steel. Appl.Surf. Sci., 252(24), 8521-8525.

10. El-Etre, A. Y, Abdallah, M. \& El-Tantawy, Z.E. (2005). Corrosion inhibition of some metals using lawsonia extract. Corrosion Sci., 47(2): 385-395.

11. Gunasekaran, G., and Chauhan, L. R. (2004). Eco friendly inhibitor for corrosion inhibition of mild steel in phosphoric acid medium. Electrochim. Acta, 49 (25): 43874395.

12. Sethuraman, M. G. \& Raja, P. B. (2005). Corrosion inhibition of mild steel by Datura metel in acidic medium. Pigment Resin Technol., 34(6): 327-331

13. Ashassi-Sorkhabi, H. and Asghari, E. (2008). Effect of hydrodynamic conditions on the inhibition performance of 1-methionine as a "green" inhibitor. Electrochim. Acta 54(2):162-167.

14. Satapathy, A. K., Gunasekaran, G., Sahoo, S.C., Kumar, A. \& Rodrigues, P.V. (2009). Corrosion inhibition by Justicia gendarussa plant extract in hydrochloric acid solution. Corrosion Sci., 51(12): 2848-2856.

15. Solomon M.M., Umoren S.A., Udosoro, I. I. \& Udoh, A.P. (2008). Inhibitive and adsorption behavior of carboxymethyl cellulose on mild steel corrosion in sulphuric acid solution. Corrosion Sci., 52(4): 1317- 1325.

16. Zhang, D.Q., Cai, Q.R., Gao,. Z. X. and Lee, K. Y. (2008). Effect of serine, threonine and glutamic acid on the corrosion of copper in aerated hydrochloric acid solution. Corrosion Sci., 50(12):3615-3621

17. Ostovari, A., Hoseinieh, S.M., Peikari, M., Shadizadeh, S.R. \& Hashemi, S. J. (2009). Corrosion inhibition of mild steel in $1 \mathrm{M} \mathrm{HCl}$ solution by henna extract: A comparative study of the inhibition by henna and its constituents (Lawsone, Gallic acid, [alpha]-dGlucose and Tannic acid). Corrosion Sci., 51(9): 1935-1949.

18. Okafor, P.C, Ikpi, M. E, Uwah, I. E, Ebenso, E. E., Ekpe, U. J. and Umoren, S.A. (2008). Inhibitory action of Phyllanthus amarus extracts on the corrosion of mild steel in acidic media. Corrosion Sci., 50 (8), 2310- 2317.

19. Olusegun, K. A. and James, A. O. (2010). The effects of Aloe vera extract on corrosion and kinetics of corrosion process of zinc in $\mathrm{HCl}$ solution. Corrosion Sci., 52: 661-664.

20. Eddy, N. O. (2009). Ethanol Extract of Phyllanthus Amarus as a Green Inhibitor for the Corrosion of Mild Steel in H2SO4., Portugaliae Electrochim. Acta, 27(5): 579-589.

21. Nelson, T. A., Charles, K., Charles, E. N. (2019). Corrosion Resistivity of Reinforced Steel in Concrete with Invingia Gabonensis Exudates / Resins Coated Steel. European Academic Research, 7 (7): 3362- 3380, 2019

22. Charles, K.., Nzidee, L. F., Charles, E. N. (2019). Corrosion Potential Assessment of Reinforcement Mechanical Properties Embedded in Concrete in Accelerated Corrosive 
Medium. International Journal of Emerging Trends in Engineering and Development, 6 (9): $1-13$.

23. González, J.A. Andrade, C. Alonso, C. and Feliu, S. (1995). Comparison of Rates of General Corrosion and Maximum Pitting Penetration on Concrete Embedded Steel Reinforcement. Cement and Concrete Research, 25:257-264.

24. Song, G. (2000). Theoretical Analysis of the Measurement of Polarization Resistivity in Reinforced Concrete. Cement and Concrete Composites, 22: 407-415.

25. Charles, K. Bright, A. Irimiagha, P, G. (2018). Investigation on Mechanism of Steel Bar Corrosion of Reinforced Concrete Structures in Aqueous Solution Using Wenner Technique. International Journal of Scientific and Engineering Research, (9)4: 1731 1748.

26. Daso, D., Charles, K., Bright, A. (2019). Evaluation of Mechanical Properties of Corroded and Coated Reinforcing Steel Embedded in Concrete. Global Scientific Journal, 7(9): 1140 - 1154.

27. Charles, K., Irimiagha, P. G., Bright, A. (2018). Investigation of Corrosion Potential Probability and Concrete Resistivity of Inhibited Reinforcement Chloride threshold in Corrosive Environment. International Journal of Scientific \& Engineering Research, 9(4): 1696 - 1713.

28. Charles, K., Taneh, A. N., Watson, O. (2018). Electrochemical Potential Investigation of Inhibited Reinforcement Properties Embedded in Concrete in Accelerated Corrosive Medium. International Journal of Scientific \& Engineering Research, 9(4): 1608 - 1625.

29. Charles, K., Philip, K. F. O., Taneh, A. N. (2018). Corrosion Potential Assessment of Eco-friendly Inhibitors Coated Reinforcement Embedded in Concrete Structures in Severe Medium. International Journal of Scientific \&Engineering Research, 9(4): 1590 1607.

30. Charles, K., Philip, K. F. O., Watson, O. (2018). Comparative Half Cell Potential and Concrete Resistivity Corrosion Probability Assessment of Coated Steel Reinforcement in Concrete Accelerated Environment. International Journal of Scientific and Engineering Research, 9(4): $141-159$.

31. Petaba, L. D., Charles, K., Kanee, S. (2019). Electrochemical Corrosion Measurement of Non-Inhibited and Inhibited Reinforcement Mechanical Properties Embedded in Concrete, "International Journal of Scientific and Engineering Research, 10(9): 1180 1196.

32. Terence, T. T. W., Kanee, S., Charles, K.. (2019). Corrosion Influence on Mechanical Properties of Corroded and Inhibited Steel Bars in Concrete with Applied Currents Potential Measurement. American Journal of Engineering Research, 8(10): 135-145.

33. BS 882; - (1992). Specification for aggregates from natural sources for concrete, British Standards Institute. London, United Kingdom,

34. BS EN 196-6; - (2010). Methods of Testing Cement. Determination of fineness, British Standards Institute. London, United Kingdom,

35. BS 12390-5; - (2005). Testing Hardened Concrete: Flexural Strength Test of Specimens, British Standards Institute. London, United Kingdom.

36. BS 4449:2005+A3 -Steel for Reinforcement of Concrete. British Standards Institute. London, United Kingdom, 2005.

37. Stem, M., and Geary, A. L. (1957). Electrochemical Polarization: a Theoretical Analysis of the Shape of Polarization curves. Journal of the Electrochemical Society, 104: 56-63.

38. ASTM Standard C876 - (2012). Standard test method for corrosion potentials of uncoated reinforcing steel in concrete, A. International, Editor. ASTM International: West Conshohocken, PA. 
DOI : https://dx.doi.org/10.26808/rs.ed.i11v5.04

International Journal of Emerging Trends in Engineering and Development Issue 11, Vol.5 (Aug-Sep 2021)

Available online on http://www.rspublication.com/ijeted/ijeted_index.htm

ISSN 2249-6149

39. ASTMC876-91: - (1999). Standard Test Method for Half-cell Potentials of Uncoated Reinforcing Steel in Concrete

40. Vesikari, E. (1988). Service life of concrete structures with regard to corrosion of reinforcement. Espoo, Finland.

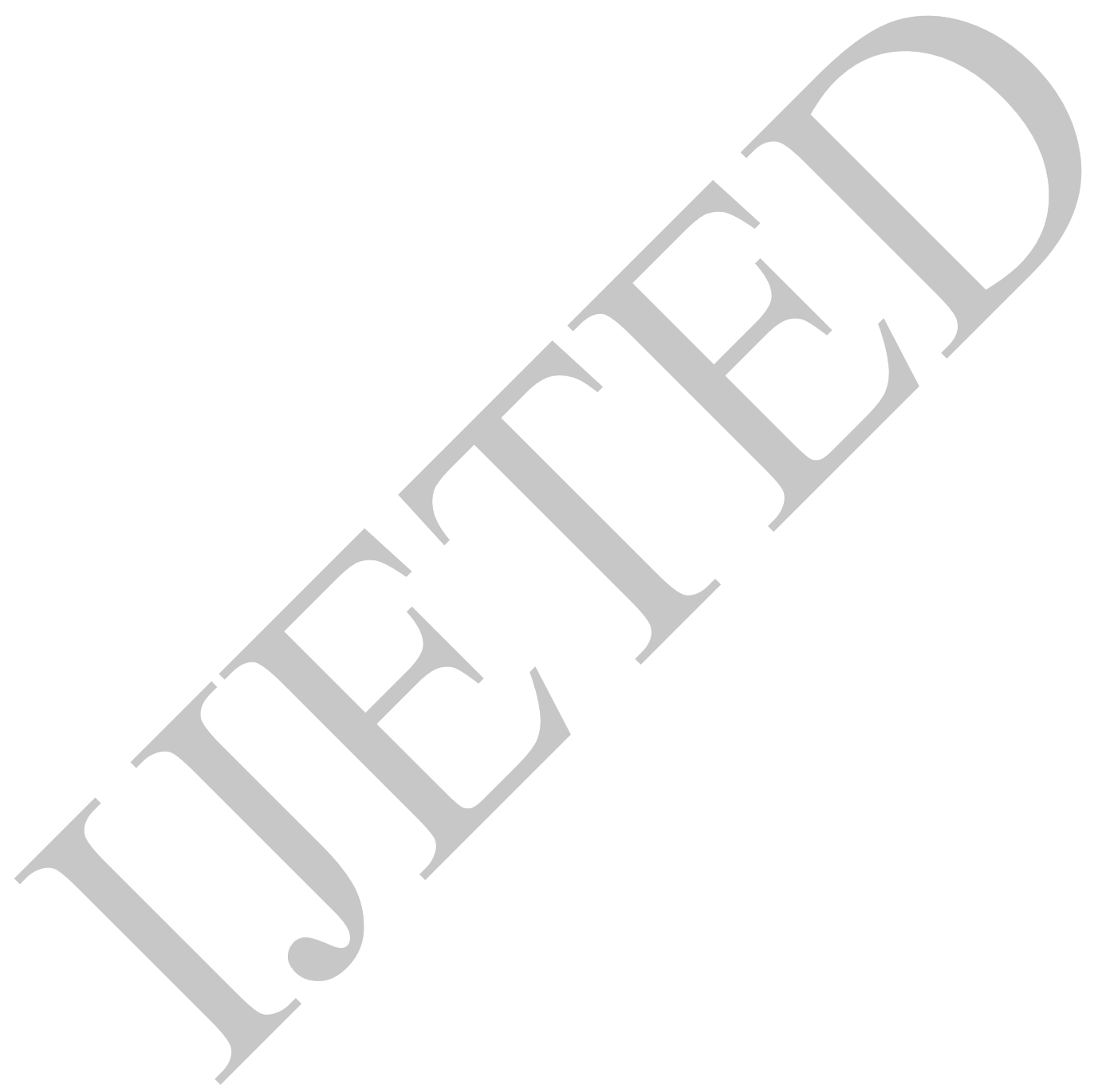

